\title{
Exedra: il disegno dello spazio romano tra geometria e percezione
}

\author{
Luca Ribichini \\ Vito Rocco Panetta \\ Antonio Schiavo \\ Lorenzo Tarquini \\ Ivan Valcerca
}

\section{Abstract}

II presente contributo mira a illustrare come, partendo dall'architettura romana, in particolare quella esistente nella città di Roma, sia stata data importanza alle forme geometriche curve (propriamente le esedre), per disegnare lo spazio urbano. Tale elemento caratteristico si è riproposto nelle diverse epoche, declinandosi sempre alla luce di soluzioni innovative, seppur collegate al passato, e costantemente in dialogo con l'intima vocazione dei luoghi.

La capacità di utilizzare forme geometriche curve che, meglio di altre, sembrano 'accogliere' lo spazio, ha posto importanti basi storiche e formali nella cultura romana che potrebbero aver condizionato il disegno urbano e lo sviluppo di parti rilevanti dell'Urbe.

L'idea, ancora da approfondire, è che esista un denominatore comune che, in modo assai complesso, diviene il dato identificativo della città stessa e, come dice Roberto De Rubertis nel libro Darwin architetto, può determinare una sorta di selezione naturale dove alcuni tratti o elementi risultano essere dominanti e decisivi venendo reiterati fino a incarnare l'anima della città stessa.

La curva, in questo caso l'esedra, amplifica lo spazio e crea occasione di scambio e connessione. Laddove la linea retta crea un movimento legato idealmente alla progressione, la curva diventa invece un luogo organizzato, spesso legato alla sensazione dell'accogliere e del ricevere, sia per la vita pubblica, sia come quinta scenica, sia come luogo.

Obiettivo di questa ricerca è quello di cercare, e quindi trovare, i collegamenti logici tra le forme e il disegno di architettura, studiando gli effetti che questi luoghi inducono nell'inconscio collettivo e tentando anche di delineare, attraverso alcuni esempi qualificanti, un excursus temporale e percettivo, di carattere culturale e psicologico, fra l'uomo dell'antichità e quello della contemporaneità.

Parole chiave

esedra, curva, geometria, spazio, architettura romana.

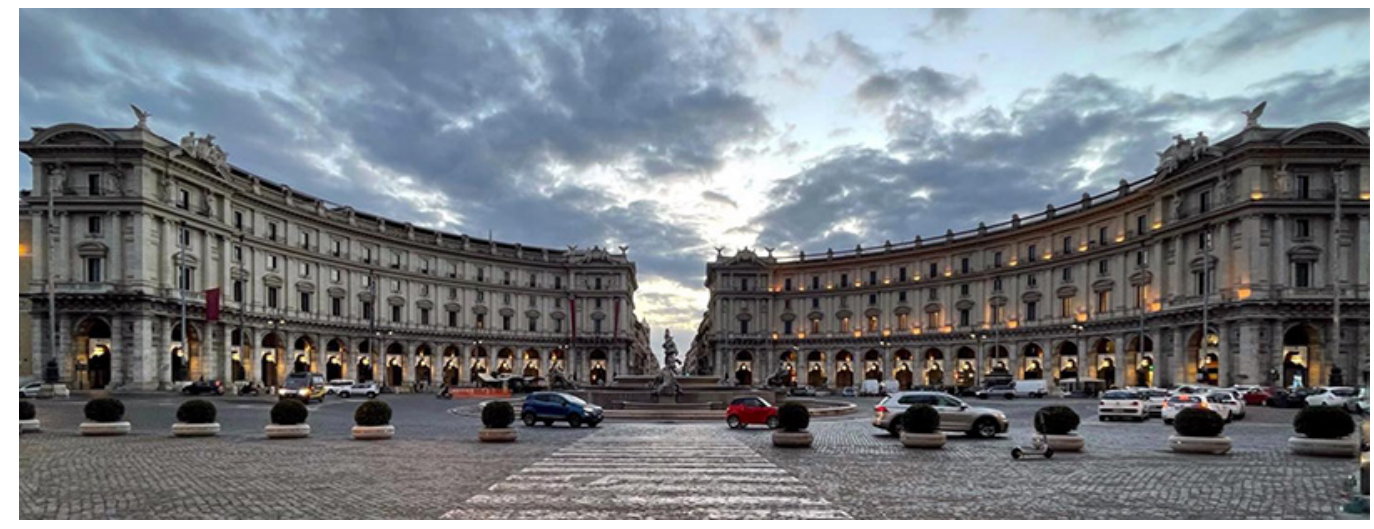


"Non è l'angolo retto che mi attira, neppure la linea retta, dura, inflessibile, creata dall'uomo. Quello che mi attira è la linea curva, libera, sensuale. La linea curva che ritrovo nelle montagne del mio paese, nel corso sinuoso dei suoi fiumi, nelle nuvole del cielo, nel corpo della donna amata. L'universo interno è fatto di curve. L'universo curvo di Einstein".

[Oscar Niemeyer]

\begin{abstract}
"Arco non è altro che una fortezza causata da due debolezze, imperò che l'arco negli edifizi è composto di 2 parti di circulo, i quali quarti circuli, ciascuno debolissimo per sé, desidera cadere, e opponendosi alla ruina l'uno dell'altro, le due debolezze si convertano in unica fortezza".
\end{abstract}

[Leonardo da Vinci]

\title{
La curva come innovazione culturale
}

La linea curva rappresenta uno degli aspetti più caratterizzanti lo spazio dell'architettura di Roma, sia del periodo antico che moderno. In particolare, si analizzerà l'esedra - dal greco

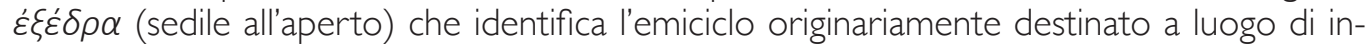
contro, di riunione e di conversazione - che, con continuità formale nel tempo, è possibile rintracciare negli edifici pubblici e privati.

A differenza di un tratto di linea retta, la cui dimensione 'finita' preannuncia una percorrenza o una direzionalità, la linea curva genera e rimanda ad altre percezioni. Ė un'affermazione del movimento, dell'onda, del rifiuto alla ripetizione e alla rigidità; è quindi un invito alla flessibilità e alla mutevolezza. Fra le tante altre evocazioni, dal punto di vista percettivo, genera sovente, in riferimento alla parte concava, interna alla curva, una sensazione di spazio che avvolge, che protegge, che ripara e che accoglie. Pertanto, nella curva si intrecciano diverse sollecitazioni, a livello sia morfologico sia ideologico sia percettivo, che collegano talune opere di architettura romana, prodotte nell'arco di oltre due millenni, all'unico ambito del Genius Loci o, in definitiva, allo spirito del luogo.

Prendendo spunto principalmente dalla tradizione costruttiva etrusco-latina, la sapienza romana svilupperà le sue potenzialità architettoniche, in pianta e in alzato, arrivando a ottenere traguardi importanti sotto diversi profili: sia spaziale sia strutturale sia psicologico.

Fig. I. In ordine dall'altro partendo da sinistra: Tempio della Fortuna Mercati di Traiano, Piazza Mercati di Traiano, Piazza San Pietro, Piazza Esed Piazza del Popolo e Unite, a Roma.

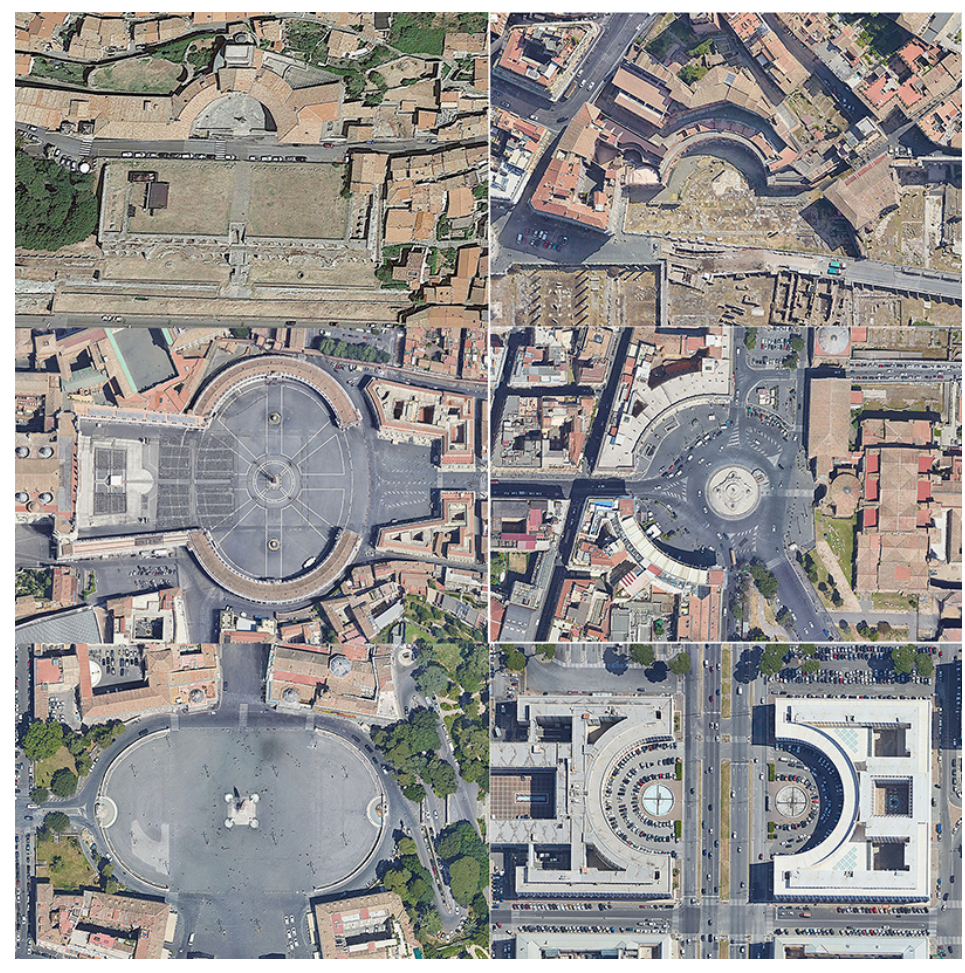


La concezione della curva, come evoluzione del concetto trilitico, diffuso sin dai tempi più antichi, si afferma con nuove pratiche del costruire derivate della necessità di ampliare, declinare e interpretare gli spazi con espressioni più auliche - generate per effetto di movimenti di rotazione o rivoluzione delle forme - quali archi, volte e cupole.

In architettura, la linea curva diventa pertanto la rappresentazione semantica dell'evoluzione geometrico spaziale dei Romani che, a differenza di altre culture del mondo antico, edificavano i loro spazi decontestualizzandoli dall'ambiente stesso in cui li innestavano.

Se l'architettura greca aveva basato le sue realizzazioni preminentemente sulla poetica della linea retta, quella romana aveva eletto la curva quale generatrice formale dei propri principi compositivi utilizzandola sia in orizzontale, per le piante di absidi, rotonde ed esedre, sia in verticale per l'alzato di archi, volte e cupole.

Nel caso emblematico del teatro, mentre gli architetti greci sfruttavano i declivi naturali adattando la cavea alle caratteristiche del sito, i Romani realizzavano le loro costruzioni in forma autonoma, a prescindere dal luogo prescelto. E, grazie anche alla loro capacità tecnica-costruttiva, avevano elaborato le procedure necessarie a rendere tale oggetto architettonico completamente indipendente da qualsiasi vincolo ambientale, naturale o spaziale (perfezionandolo poi in chiave di anfiteatro ed esportandolo in tutto l'impero).

\section{Geometria atemporale}

Ma vediamo quali possono essere gli esempi costitutivi dell'esedra, che ne determinano la sua particolarità. Secondo alcuni studiosi, la prima espressione disegnata in tal senso potrebbe essere ricondotta alla costruzione dell'esedra che corona il 'santuario superiore' della Fortuna Primigenia (metà del II secolo a.C.). Questo grande emiciclo, concluso da ali laterali rettilinee, è caratterizzato da due file di colonne che generano un doppio porticato a navate ricurve. Tale spazio concavo recinge a sua volta una cavea a gradoni la cui corda misura circa $47 \mathrm{~m}$. Sulla sommità dell'esedra, un tempio circolare (di cui oggi restano solo le fondazioni) coronava l'intero complesso, dando vita a un interessante gioco di linee concave e convesse. Un altro edificio ad andamento curvilineo si trova nella Villa a esedra dell'Acqua Claudia, ad Anguillara Sabazia, realizzata circa un secolo dopo il tempio della Fortuna Primigenia. La

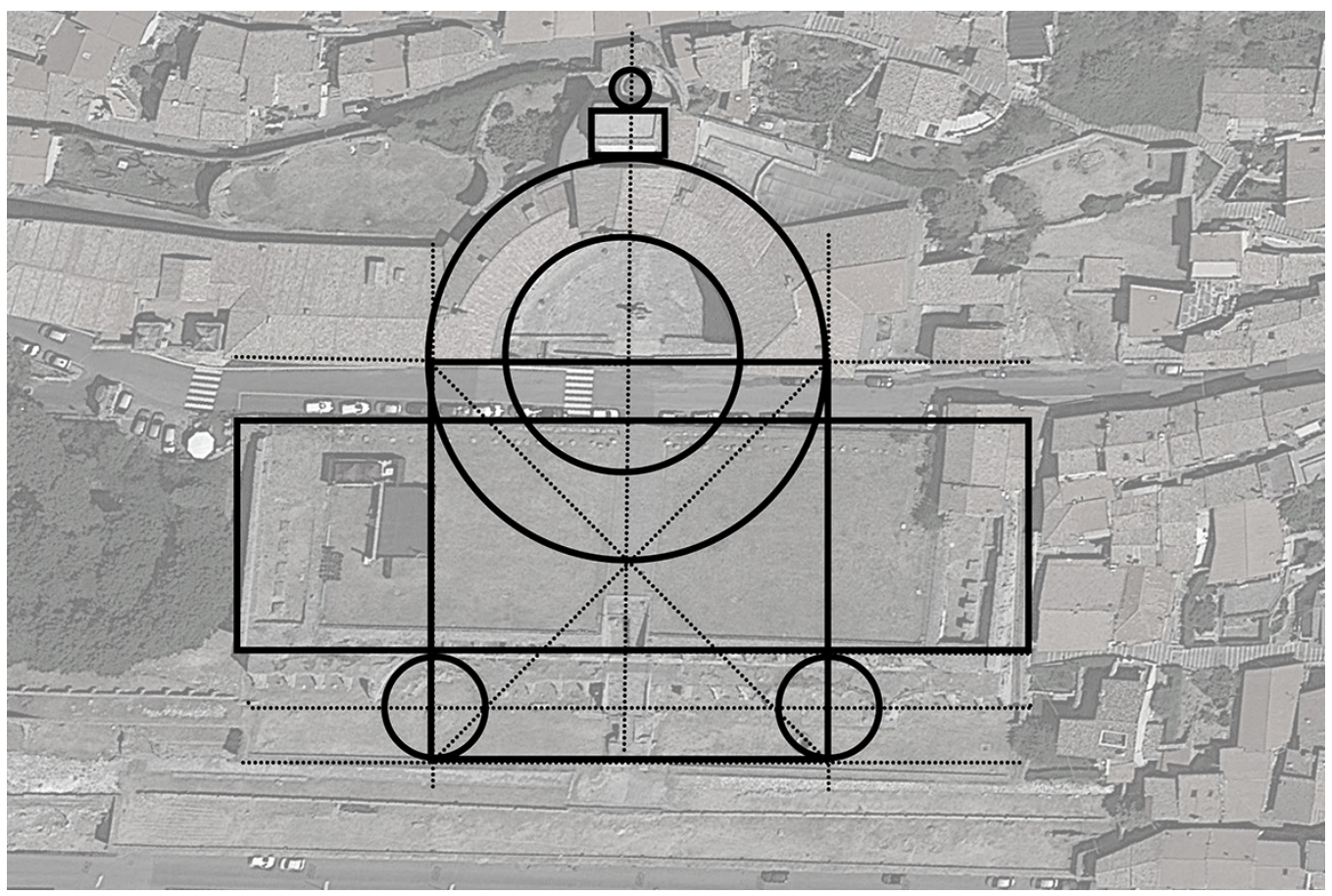


costruzione presenta una morfologia che rimanda fortemente all'esempio di Palestrina per via di un'impostazione analoga, su un'ampia esedra costituita da un arco di circonferenza, tuttavia ancora lontano dall'essere un semicerchio e con delle terminazioni lineari e speculari ai lati. Ma la novità spaziale, rappresentata dalla conformazione a nicchie dell'esedra, conferisce una percezione di arricchimento e di ulteriore movimento e dinamicità.

Fig. 3. Rovine romane della villa a esedra dell'Acqua Claudia ad Anguillara Sabazia.

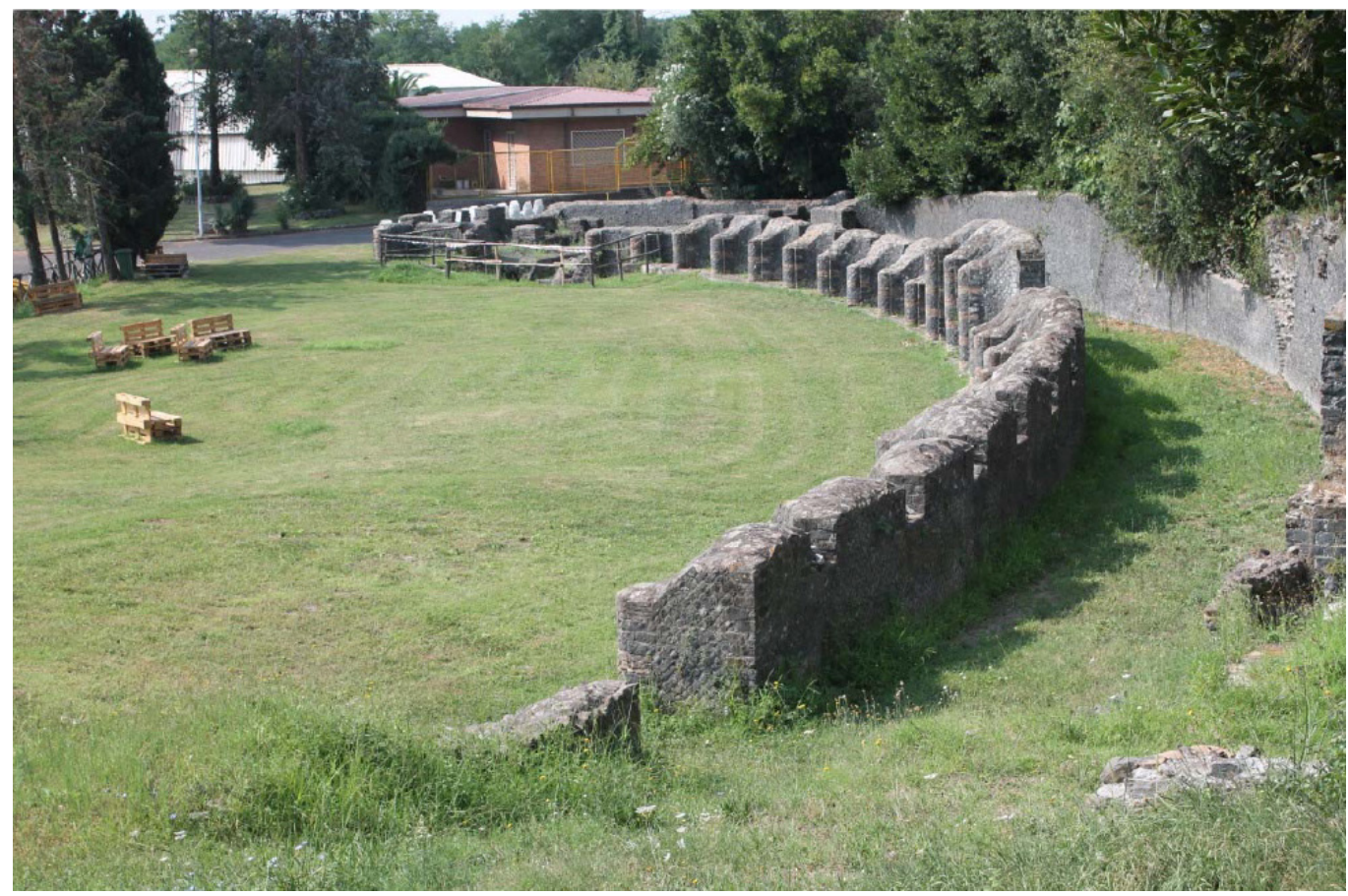

Dove lo sviluppo dell'architettura curvilinea si accentua e sensibilmente 'prende forma' è, nella costruzione del Foro di Augusto a Roma. Qui due coppie di esedre, con funzione di tribunalia e realizzate in maniera simmetrica, sono impostate perpendicolarmente all'asse principale su cui insiste il tempio di Marte Ultore. Rispetto all'esempio precedente l'esedra acquisisce caratteri aulici, divenendo progressivamente simbolo della grandiosità dell'architettura imperiale che "troverà nella linea curva uno dei suoi mezzi d'espressione più originali e più efficaci, $[\ldots]$ dove raggiungerà effetti di solennità che rimarranno insuperati. Si osservi [inoltre] come il grado di curvilinearità $[. .$.$] già accentuatosi negli emicicli del Foro di Augu-$ sto, raggiunga nell'esedra traianea il perfetto semicerchio" [Vighi 194I, pp. I5 | I 53].

II Vighi, archeologo studioso della linea curva romana, ci propone il collegamento proprio con la costruzione di Traiano. È probabile, infatti, che il massimo grado di sofisticatezza dell'applicazione dell'esedra si raggiunge proprio nei MercatiTraianei.Tra le tante motivazioni della forma curva, la prima ragione è essenzialmente di carattere strutturale. L'esedra dei mercati si configura costruttivamente come un arco ribaltato con la funzione di contenere la spinta del terreno della collina retrostante. II Foro di Traiano e i relativi mercati nascono infatti dalla cesura della sella che collegava i colli Quirinale e Campidoglio. La morfologia degli stessi è dunque figlia di un'esigenza prettamente strutturale, una parete curvilinea contro-terra - un prospetto monumentale al taglio del colle - che si eleva a manifesto architettonico con dei valori sia simbolici sia prettamente funzionali. Anche la relativa basilica Ulpia differisce dalle basiliche più antiche, la Julia e la Aemilia, per la presenza di due absidi aventi come diametro la lunghezza delle tre navate interne. Esse dialogano formalmente con le esedre del Foro, condividendo inoltre la probabile funzione di tribunalia.

Da queste architetture si evince chiaramente come la presenza dell'esedra (o comunque di una superficie inflessa), rispetto agli involucri spaziali piani, offra tre tipi di vantaggi: il primo perché conferisce maggiore solennità e maestosità alla costruzione, il secondo perché de- 
termina una più adeguata e sapiente distribuzione dello spazio, l'ultimo, ma non per questo trascurabile, perché ottiene un risultato scenografico più rilevante, facendo leva su valori prospettici ed effetti chiaroscurali di maggiore grandiosità.

In perfetta continuità con l'architettura traianea, la Villa di Adriano (76-I 38 d.C.) a Tivoli, dal canto suo, rappresenta la summa della ricerca compositiva romana, in cui il tema della linea curva viene approfondito e ulteriormente esaltato. L'ambiente mistilineo delle Piccole Terme caratterizzate da un ottagono con quattro lati convessi, la Piazza d'Oro, il cui padiglione di fondo, impostato su una sagoma cruciforme, è caratterizzato da un'inedita linea sinuosa concavo-convessa, e infine le soluzioni plastiche del Teatro Marittimo, sembrano i frutti di sofisticati giochi compositivi, in cui ben si sposano ricchezza creativa e sapienza costruttiva. Oltre a questi esempi più specifici, anche nella sua totalità concettuale,Villa Adriana si palesa come la vera svolta decisiva dell'architettura romana: qui infatti "le masse murarie plasmano gli spazi interni ed esterni" [Bozzoni et al. 2006, pp. 33 I-332], affrancandosi dalla regola degli ordini architettonici ma rispondendo a dei chiari motivi espressivi, che potremmo riassumere, citando il moderno Luigi Moretti, come "sentimenti di espansione".

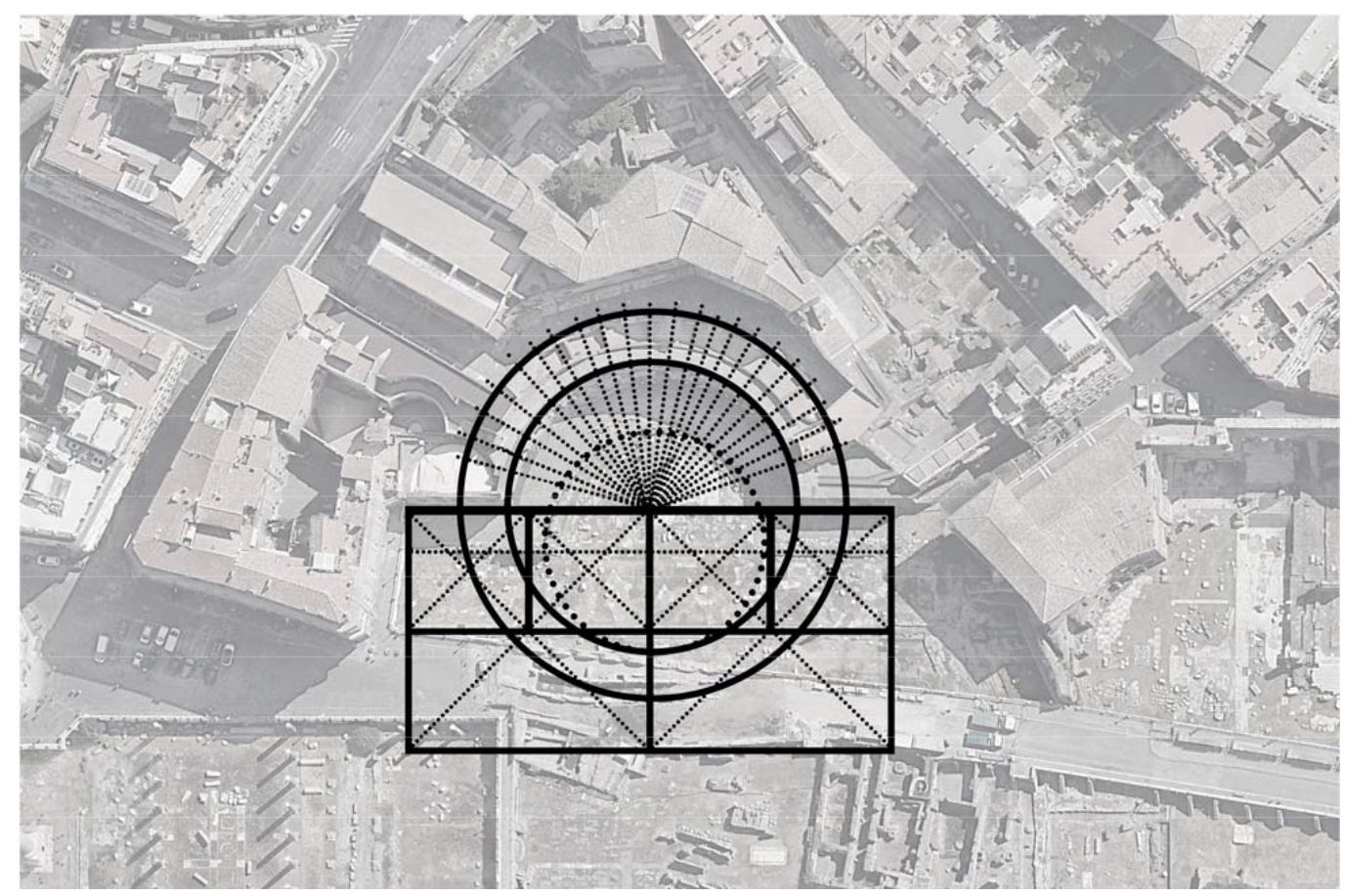

Non è azzardato dunque congiungere idealmente l'architettura di Villa Adriana al barocco romano, e ciò è affermato da molti critici e storici, alcuni dei quali affermano che "ormai la linea curva, magistralmente trattata nelle diverse combinazioni e nei più armonici sviluppi, è parte integrante del linguaggio architettonico di Roma: e già va animando dei suoi accenti quelle mirabili creazioni in Italia e ancor più nelle provincie, il cui stile, quale precorritore del Seicento italiano, ha ricevuto la denominazione di 'barocco antico'" [Vighi 194I, p. I53]. Proprio nel Seicento si pone il problema della creazione di un 'luogo' antistante alla basilica di San Pietro. Uno spazio monumentale e rappresentativo, avente il ruolo di anticamera alla basilica, capace di conciliare diversi elementi eterogenei, di natura architettonica, urbanistica e funzionale.

La scelta definitiva di Gian Lorenzo Bernini (I598-1680) ricade su un ovato tondo, che rispetto all'ellisse è di più facile realizzazione oltre che concettualmente congruo alla politica di controriforma lanciata dalla chiesa, in risposta al fermento protestante che divampava culturalmente in Europa. L'ellisse, infatti, era la rappresentazione 'eretica' delle nuove scientificità, mentre l'ovale era, secondo la visione cattolica, una corretta evoluzione del cerchio, ente geometrico perfetto, base della geometria euclidea. 


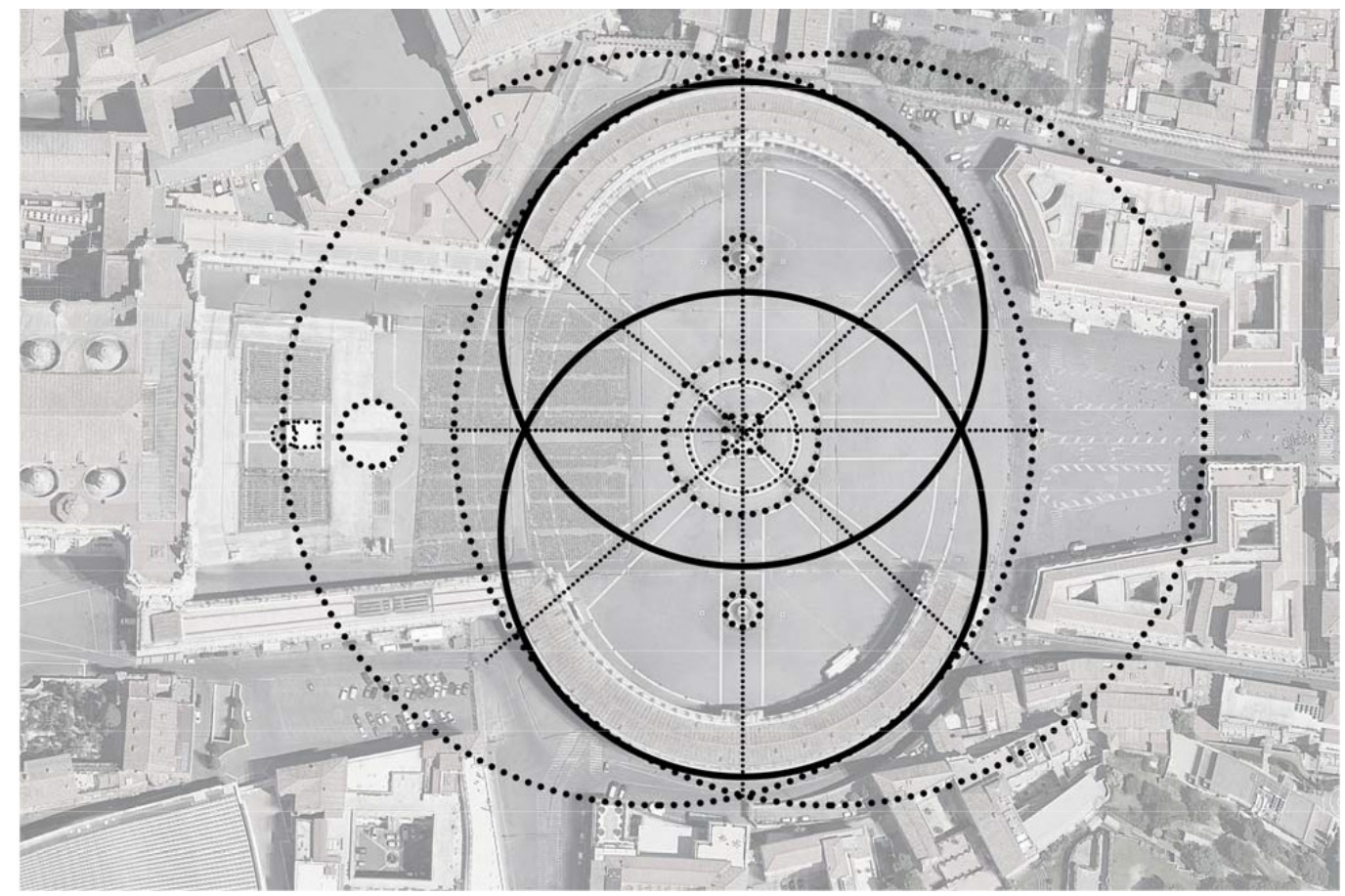

Ciò dà vita al disegno di uno spazio dinamico, superando la staticità e l'eccessiva regolarità del cerchio. Ai lati della piazza due ampie esedre costruite sugli archi di circonferenza sono conformati da una selva di pilastri con la duplice funzione di filtro, rispetto agli ambiti urbani preesistenti, e di abbraccio simbolico verso i fedeli.

A livello percettivo la scelta del Bernini è confermata dalle parole di Heinrich Wöfflin, secondo il quale: "il barocco non dà mai il finito e l'appagato, non la calma dell'essere, ma l'agitazione del divenire, la tensione di uno stato mutevole. E da ciò deriva, in altra maniera, un nuovo senso del movimento. A questo appartiene il motivo della 'tensione nelle proporzioni'. Il cerchio è una forma calma, immutabile; l'ovale è irrequieto e sembra tendere al continuo mutamento. Ė privo di necessità. II barocco per principio crea queste proporzioni "libere". II finito, il completo, è contrario alla sua natura" [Wöfflin 20 I 0, p. 72]. E ancora Wöfflin fa una considerazione proprio sulla linea curva "che sostiene il movimento dell'occhio che segue la linea, ridisegnandola [...] e in ciò spiegherebbe il piacere causato dalle linee curve. La bellezza della forma [curva] sarebbe identica alla convenienza dell'occhio" [Wöfflin 20 I I, pp. I4, I5]. In questa sede tralasceremo di parlare di Piazza del Popolo e delle sue esedre progettate in epoca napoleonica dal Valadier, ma ci concentreremo sulla ricerca di uno stile nazionale, all'indomani della breccia di Porta Pia. Gaetano Koch (I849-1910) suggerì dunque il disegno dell'attuale Piazza della Repubblica (già Piazza Esedra). Gli edifici porticati nascono dall'idea di sovrapporsi alle vestigia delle antiche Terme di Diocleziano e in particolare della grande esedra romana. La preesistenza dell'asse di via Nazionale impose all'architetto di origini tirolesi la realizzazione di due emicicli asimmetrici, considerato il leggero disassamento della via rispetto al centro dell'esedra. Koch tentò di correggere la leggera asimmetria con l'imposizione di profili rettilinei nei pressi dell'imbocco di via Nazionale, rendendo apparentemente impercettibile la differenziazione. Questa operazione di sovrapposizione ci rammenta il pensiero che Sigmund Freud ha espresso proprio su Roma quando sottolinea l'unicità di questa capitale e la paragona a una un'entità psichica dove le cose si stratificano come nella coscienza umana e come d'incanto emergono in modo evidente, fondendosi l'una con l'altra creando un unicum. Più di cent'anni prima, nel I786, anche Johann Wolfgang Goethe (I 749- | 832), durante il suo Viaggio in Italia, aveva intercettato la specificità di Roma in quella realtà multistratificata tramite la quale la città nuova nasce dall'antica ed entrambe coesistono in un 'corpo vivo' unico. 


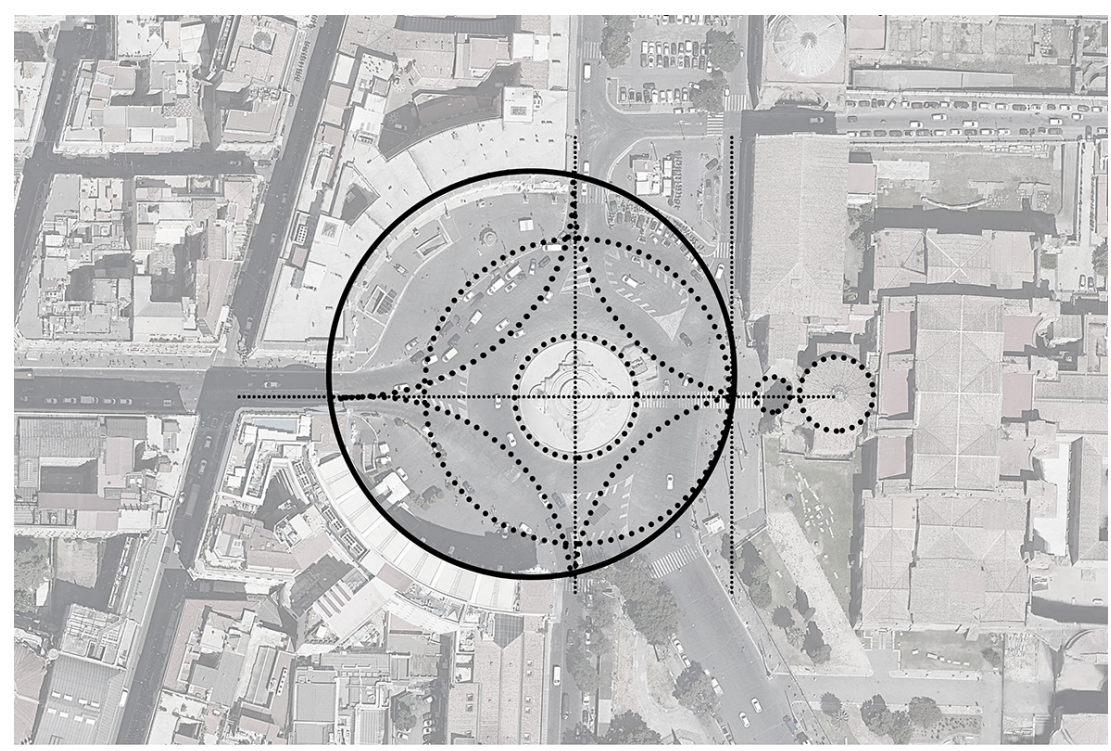

Fig. 7. Analisi geometrica di Piazza del Popolo.
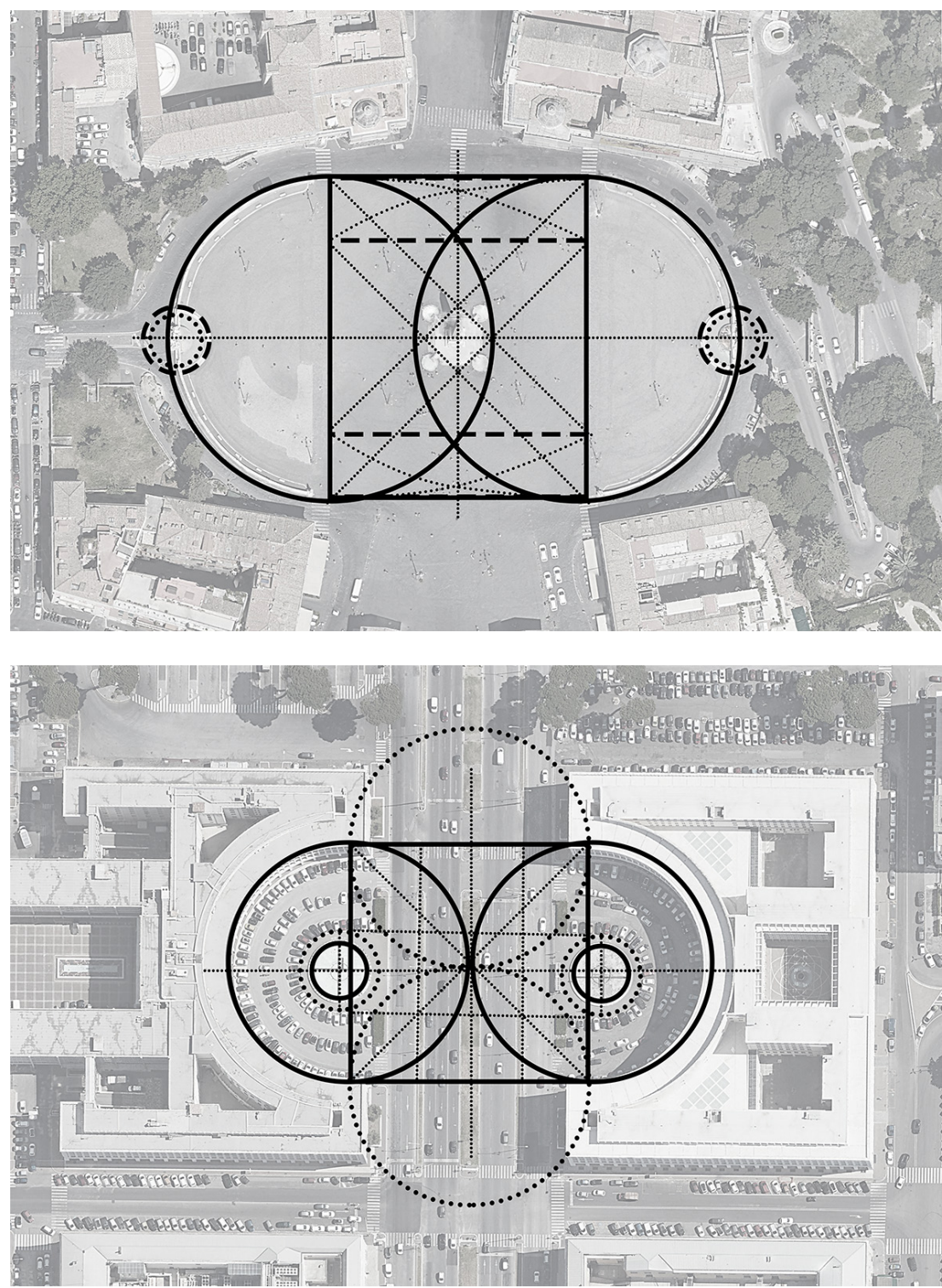
Nell'ambito del progetto urbano per l'esposizione Universale del 1942, di cui si tralascia in questa sede ogni disamina, vale la pena ricordare i due edifici a esedra - comunque ispirati ai Mercati di Traiano - che Giovanni Muzio, Mario Pediconi e Giulio Paniconi hanno progettato come quinte architettoniche poste ai rispettivi lati della cosiddetta 'porta imperiale'.

L'obiettivo di riprendere il filo dello spirito architettonico di Roma antica emerge in maniera fin troppo evidente con il concorso per il Palazzo del Littorio da edificarsi lungo la neonata via dell'Impero. Ė il 1934. Adalberto Libera (1903- 1963) decide di disegnare il suo progetto in modo da legarsi idealmente all'emiciclo dei MercatiTraianei caricando le forme di valenze simboliche, tra monumentalità e misticismo, e cercando di dialogare in maniera diretta con l'abside della vicina Basilica di Massenzio.

Con pochi segni, egli riesce a consegnare unitarietà all'idea di astrazione del classico, sfociando in un'immagine dal carattere assoluto. Poiché il bando imponeva un grande spazio per le adunate, Libera lo risolve con una proiezione prospettica. II suo progetto si avale inoltre di un grande volume delimitato da due archi di circonferenza a raggi di grandezza differente con le pareti trasversali convergenti verso un unico punto, a metà fra i centri delle due curvature [Ciucci 200 I, p. 69]. Inoltre le testate tronche ribadiscono la natura frammentaria dell'edificio mentre la scansione orizzontale del fronte, ottenuta grazie a delle fasce vetrate, si palesa "come se il cerchio si fosse sciolto in una curva portata alla scala del paesaggio" [Garofalo 200 I, p. I5 I].
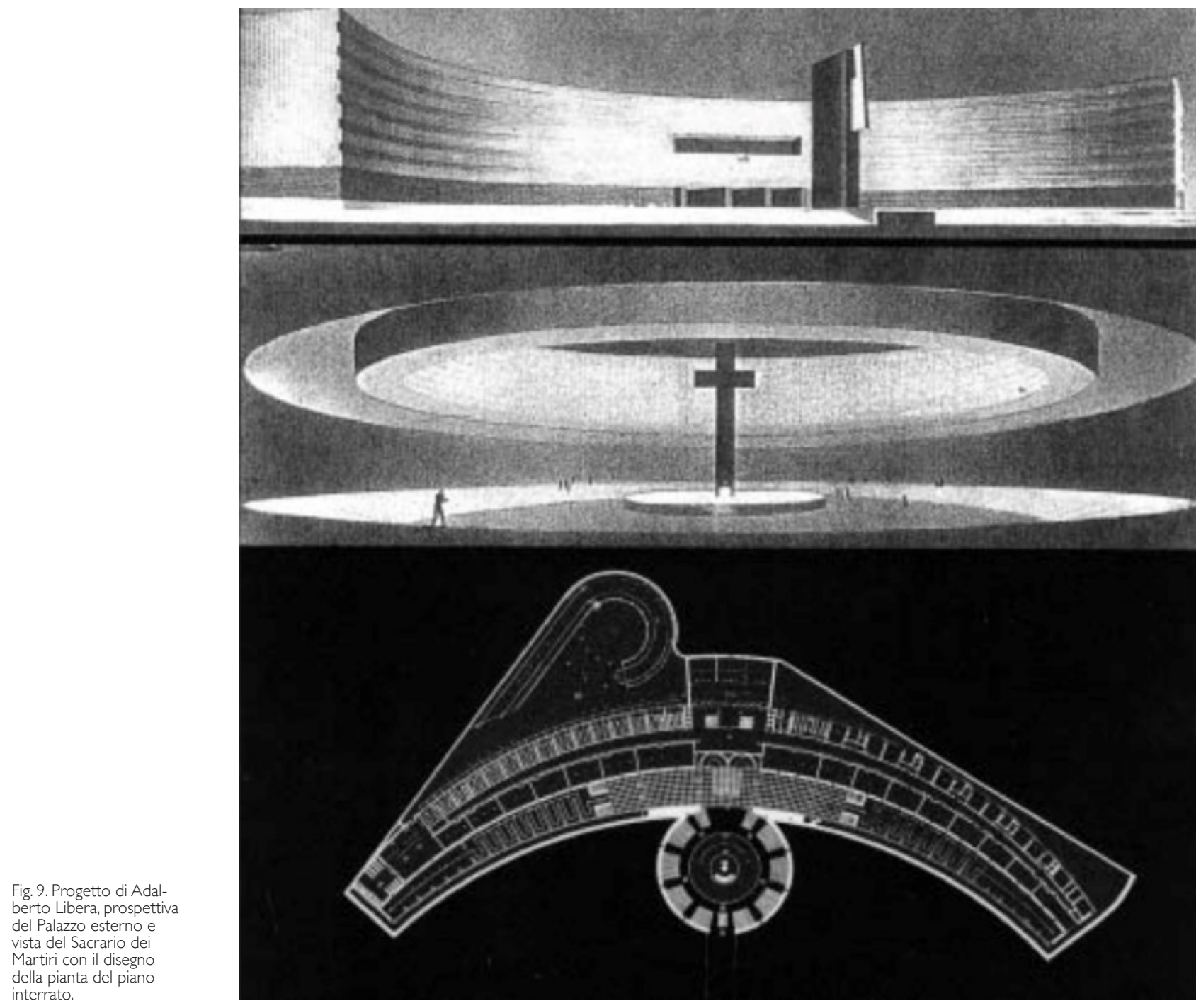


\section{Gestalt e archetipi di forme urbane}

Se ci dovessimo soffermare sulle costruzioni geometriche che regolano e descrivo gli spazi dapprima elencati, potremmo trovare delle strette relazioni con quella parte di geometria piana che per secoli ha composto e costituito lo spazio dell'uomo. Parliamo di tracciare dapprima dei centri, quindi di istituire delle centralità, per poi impostare il raggio che descriverà la circonferenza o parte di essa,'progettando' il sesto che inquadrerà la rispettiva quinta scenica e traccerà e dimensionerà i confini dello spazio costruito.

$\mathrm{Da}$ questa costruzione geometrica, basata sulle relazioni del cerchio, dove tutto è predisposto con equidistanti relazioni di tutti gli elementi in 'scena' rispetto al centro di costruzione, possiamo creare dei giochi di tensioni continui, approdando a un vero e proprio equilibrio [Arnheim 2002], semplicemente relazionando i raggi di circonferenza e i rispettivi centri fra loro. Esempio perfetto è 'l'abbraccio' berniniano a piazza S. Pietro dove l'intersezione fra le due circonferenze che disegnano le esedre laterali determinano una terza figura geometrica, connotata dall'ovale, che trasforma uno spazio centripeto in uno spazio centrifugo, suggerendo all'osservatore il movimento della percezione, in questo caso coadiuvato dalla disposizione del colonnato perimetrale. Potremmo definire il tutto come 'esperienza visiva dinamica' dove l'osservatore è spettatore stesso dell'interazione tra tensioni delle due figure geometriche generatrici che, secondo i principi della gestalt, organizzano un 'campo' in cui nessun oggetto o parte di esso viene percepito come isolato dal resto, o decontestualizzato, garantendo dunque un unicum percettivo connotante lo spazio intero.
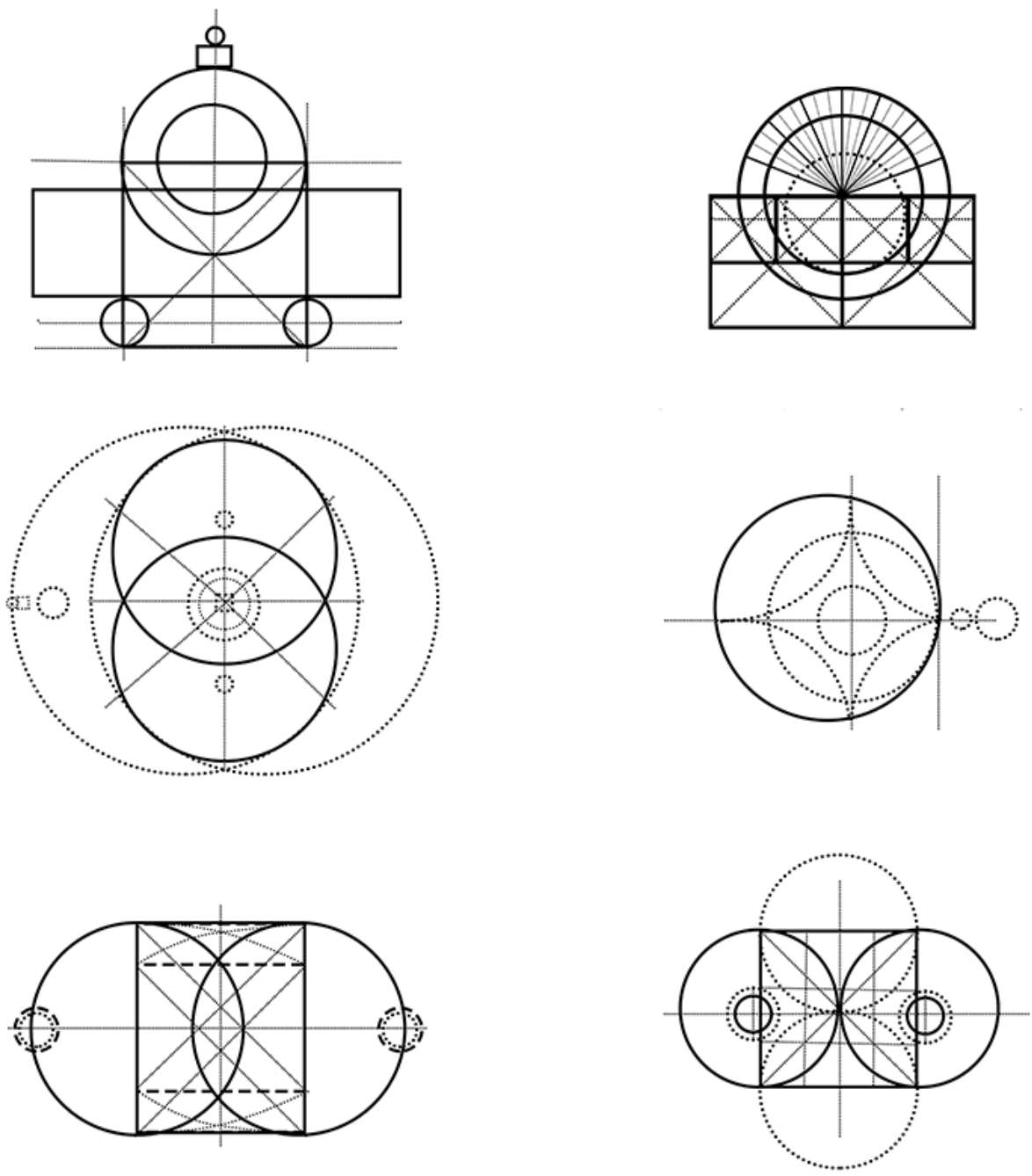
È consequenziale dedurre come, sin dall'antichità, la costruzione di spazi curvilinei abbia rappresentato la "forza archetipica" della cultura capitolina: un carattere distintivo che si è tramandato nei secoli sotto diverse forme e che ha sviluppato geometrie proprie; un vero e proprio 'segno collettivo' che, con l'ausilio di figure che planimetricamente rinviano al 'mandala' [I], è in grado di rappresentare in modo inequivocabile il disegno della città. La curva diventa così iconografica della forma urbis, il segno che maggiormente descrive il Genius Loci e la millenaria cultura di Roma.

\section{Conclusioni e considerazioni}

Le considerazioni di questo studio nascono dalla semplice osservazione del disegno planimetrico della città e dall'analisi dei suoi elementi costitutivi. L'obiettivo è quello di comprendere la genesi di uno spazio, non solo dal punto di vista geometrico, fisico e percettivo ma anche per la sua connessione con la memoria storica, tentando di rintracciare il fil rouge che, attraverso i secoli, collega i diversi esempi architettonici e cercando di capirne il 'senso'. Affrontare il tema sotto un profilo percettivo-conoscitivo permetterà di andare oltre l'evidenza dell'intelaiatura geometrica, per indagare campi dell'inconscio, per mettere in luce gli aspetti ctoni di una cultura, celati a volte da un'estetica della forma, ma esplicitati attraverso un legame culturale che li connota e li unisce attraverso il tempo.

Appare da queste brevi considerazioni l'emergere di relazioni di spazi che, a distanza di tempo, diventano identità di una città e ne connotano la propria qualità e caratteristica. In quest'ottica, sarà importante provare ad allargare il campo di indagine anche su altri luoghi romani, che nel testo sono stati appena accennati, come la villa Madama di Raffaello, Piazza del Popolo e le due esedre costruite all'EUR.

Forse si dovrebbe provare ad analizzare, in modo più sistematico, tutta la variegata casistica per cercare di far emergere quel filo di Arianna, che lega spesso molte città, ma che nondimeno rimane nascosto tra le pieghe del tessuto urbano, senza avere la capacità di rendersi evidente e riconoscibile. L'idea è che studi analoghi possano profilare una metodologia d'indagine legata ai processi cognitivi che si relazionano allo sviluppo e alla percezione di una forma. In questo caso l'esedra incarna una tradizione archetipica elaborata dal pensiero romano e la sua naturale evoluzione resta un punto fisso che condiziona e influenza altre architetture in altri luoghi.

\section{Note}

[I] Secondo C. G. Jung i 'mandala', quali figure ordinate, sia nell'antichità che nei tempi moderni, rappresentano l'estetica e l'ordine, il bisogno ancestrale del ritrovare la dimensione spirituale, il senso mistico dell'esistere: l'uomo quale essere posto tra il cielo e la terra che anela alla sintesi tra i due mondi [Jung 199I].

\section{Riferimenti bibliografici}

Arnheim R. (2002). Arte e percezione visiva. Milano: Feltrinelli.

Benevolo L. (2004). San Pietro e la città di Roma. Roma-Bari: Laterza.

Bozzoni C. et al. (2006). L'architettura del mondo antico. Roma-Bari: Laterza.

Carpiceci A. C. (1983). La Fabbrica di San Pietro, venti secoli di storia e progetti. Firenze: Bonechi.

Ciucci G. (200 I). Lo stile di Libera. In AA.VV. Adalberto Libera. Opera completa, pp. 62-79. Milano: Mondadori Electa.

Finelli L., Foà Di Castro F. (a cura di) (200I). Giulio Pediconi: un testimone imparziale. Roma: Edizioni Kappa.

Garofalo F. (200 I). Progetto per il palazzo del Littorio a Roma. Concorso di I grado, 1933-34. In AA.V. Adalberto Libera. Opera completa, pp. I50- I5I, Milano: Mondadori Electa.

Jung C. G. (1972). Psicologia e Alchimia. Torino: Bollati Boringhieri [prima ed. Psychologie und Alchemie, 1935].

Jung C. G. ( 1977). Gli archetipi dell'inconscio collettivo. Torino: Bollati Boringhieri.

Jung C. G. (199I). L'uomo e i suoi simboli. Milano:Tea [prima ed. Man and His Symbols, 1964]. 
MacDonald W. L., Pinto J. A. (2006). Villa Adriana: la costruzione e il mito da Adriano a Louis Kahn. Milano: Mondadori Electa. Marconi P. (1964). Giuseppe Valadier. Roma: Officina Edizioni.

Muntoni A. (1987). Lo studio Paniconi e Pediconi 1930-1984. Roma: Edizioni Kappa.

Muratore G. (2007). Roma. Guida all'architettura. Roma: L'Erma di Bretschneider.

Quilici V. (198I). Adalberto Libera: l'architettura come ideale. Roma: Officina Edizioni.

Spagnesi G. (2003). Roma. La basilica di San Pietro, il borgo e la città. Milano: Jaca Book.

Tucci G. (1969). Teoria e pratica del mandala. In Palladio,V, 4, pp. I45- I60. Roma: Ubaldini.

Wöfflin H. (20।0). Rinascimento e barocco. Ricerche intorno all'essenza e all'origine dello stile barocco in Italia. Milano: Abscondita [prima ed. Renaissance und Barock. Eine Untersuchung überWesen und Entstehung des Barockstils in Italien. München: Bruckmann, 1888].

Wöfflin H. (20l I). Psicologia dell'architettura. Milano: et al. [prima ed. Prolegomena zu einer Psychologie der Architektur. Basel: Schwabe AG Verlag, 1946].

Worringer W. (2008). Astrazione e empatia. Un contributo alla psicologia dello stile. Torino: Einaudi [prima ed. Abstraktion und Einfühlung. Ein Beitrag zur Stilpsychologie. München: Piper \& Co., 1908].

\section{Autori}

Luca Ribichini, Sapienza Università di Roma, luca.ribichini@uniroma l.it

Vito Rocco Panetta, Comune di Roma.

Antonio Schiavo, Sapienza Università di Roma, antonio.schiavo@uniromal.it

Lorenzo Tarquini, Sapienza Università di Roma, lorenzo.tarquini@uniroma l.it

Ivan Valcerca, Sapienza Università di Roma, ivan.valcerca@uniromal.it

Per citare questo capitolo: Ribichini Luca, Panetta Vito Rocco, Schiavo Antonio, Tarquini Lorenzo,Valcerca Ivan (2021 ). Exedra: il disegno dello spazio romano tra geometria e percezione/Exedra: designing space in Rome: geometry and perception. In Arena A., Arena M., Mediati D., Raffa P. (a cura di). Connettere. Un disegno per annodare e tessere. Linguaggi Distanze Tecnologie. Atti del $42^{\circ}$ Convegno Internazionale dei Docenti delle Discipline della Rappresentazione/Connecting. Drawing for weaving relationship. Languages Distances Technologies. Proceedings of the $42^{\text {th }}$ International Conference of Representation Disciplines Teachers. Milano: FrancoAngeli, pp. I063-1084. 


\title{
Exedra: Designing Space in Rome. Geometry and Perception
}

\author{
Luca Ribichini \\ Vito Rocco Panetta \\ Antonio Schiavo \\ Lorenzo Tarquini \\ Ivan Valcerca
}

\section{Abstract}

This contribution will illustrate how curved geometric forms, more precisely exedra, were extensively used by the Romans to design urban space, in particular in the city of Rome. This characteristic element then became popular over the centuries; although it evolved when innovative solutions were found, it is nevertheless linked to the past and dialogues constantly with the intimate vocation of sites and places.

The ability to use curved geometric forms which, compared to others, appear better suited to "embrace" space, paved the way for the establishment of important historical and formal elements of Roman culture, ones which may have influenced the urban design and development of key urban areas. The idea -still requiring further in-depth analysis- is that there is a common denominator which, in a very complex manner, became the signature style of the city and which -in the words of Roberto De Rubertis in his book Darwin architetto- can determine a sort of natural selection where some traits and elements are dominant, decisive and reiterated until they embody the city's soul.

The curve, in this case, the exedra, amplifies spaces and creates opportunities for exchange and association. Whilst the straight line creates movement ideally linked to progression, the curve instead becomes an organised place, often linked to the feeling of hospitality and reception in public life, as well as a scenic wing, and a place.

The objective of this study was to search for and identify the logical links between forms and architectural design by not only studying the effects caused by these sites in our collective unconscious, but also by outlining -using appropriate examples- a temporal and psychological overview, from the point of view of culture and psychology, between ancient and contemporary man.

\section{Keywords}

exedra, curve, geometry, space, Roman architecture.

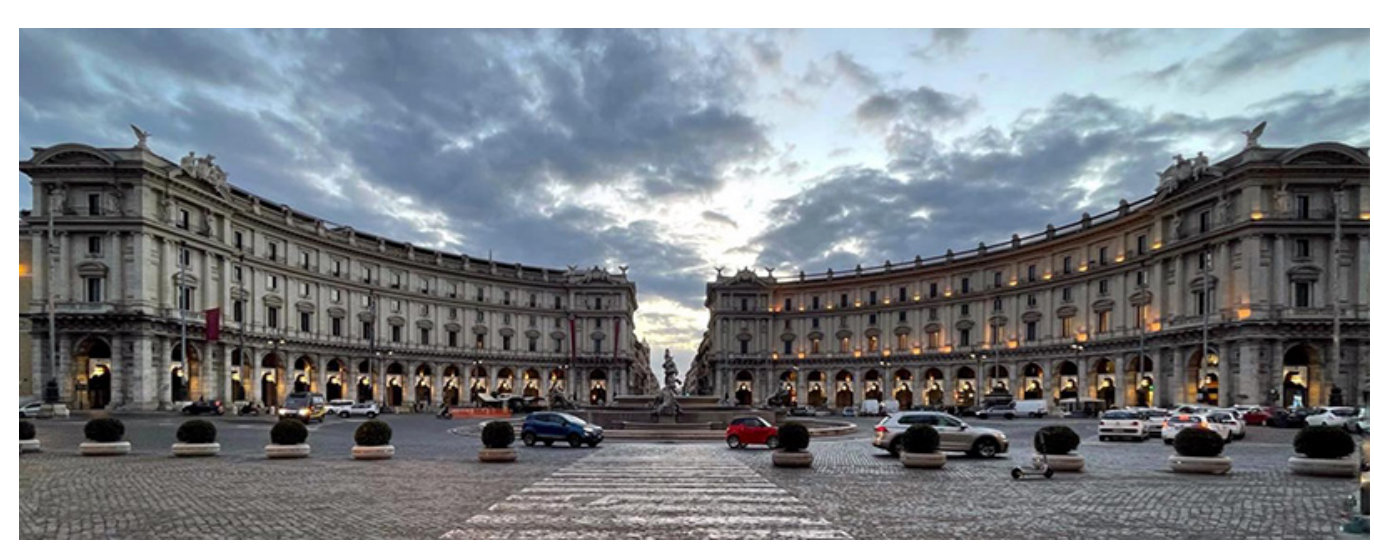


"It is not the right angle that attracts me, not the straight line, hard and inflexible, created by man. What attracts me is the free and sensual curve the curve that I find in the mountains of my country, in the sinuous course of its rivers, in the body of the beloved woman. Curves make up the entire universe, the curved universe of Einstein".

[Oscar Niemeyer]

"The arch is nothing else than a force originated by two weaknesses, for the arch in buildings is composed of two segments of a circle, each of which being very weak in itself tends to fail,

but as each opposes this tendency in the other, the two weaknesses combine to form one strength".

[Leonardo da Vinci]

\section{The curve as a cultural innovation}

A curved line represents one of the most characteristic aspects of both ancient and modern architectural space in Rome. This contribution will focus in particular on the exedra, from the Greek $\dot{\varepsilon} \xi \dot{\varepsilon} \delta \rho \alpha$ (outdoor seat), a word originally used to describe a hemicycle, a place where people could meet, assemble, and converse. Down through the ages the exedra continued to be formally present in both public and private buildings.

Unlike a straight line which, with its 'finite' dimension heralds a distance or direction, a curved line generates and recalls other perceptions. As a statement of movement, of a wave, of the rejection of repetition and rigidity, it therefore encourages flexibility and mutability. Amongst the many other perceptive evocations, its concave part inside the curve often generates a feeling of enveloping, protecting, repairing, and welcoming space. Accordingly, different morphological, ideological and perceptive stimuli are entwined in the curve, linking several architectural works in Rome, built over a period of more than 2,000 years, to the unique environment of the Genius Loci or, ultimately, to the spirit of the place.

Roman wisdom and knowledge, chiefly based on Etruscan-Latin building traditions, developed its architectural potential, in plan and elevation, ultimately achieving important spatial, structural and psychological results.

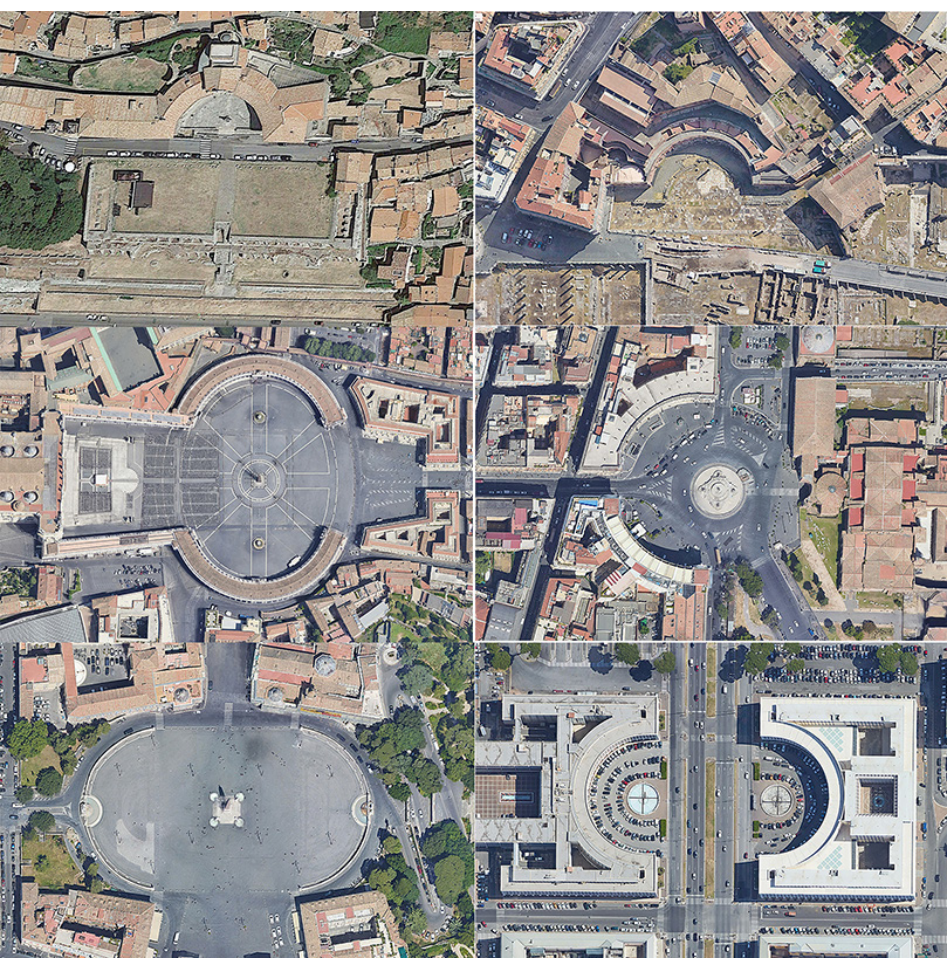


The idea of the curve, as an evolution of the trilithic concept, had been well-known since antiquity but became established when new building practices were invented because spaces needed to be enlarged, created and interpreted by more aulic elements such as arches, vaults and domes - generated by the rotation or revolution of forms.

In architecture the curved line became the semantic representation of the Romans' spatial geometric evolution which, unlike other ancient cultures, built their spaces by decontextualising them from the environment where they were situated.

While the Greeks had based their architecture predominantly on the poetics of the straight line, the Romans chose the curve as the formal generator of the compositional principles of architecture, using it horizontally for the plans of apses, rotundas and exedras, and vertically for the elevation of arches, vaults and domes.

Theatres are emblematic examples. While Greek architects exploited natural slopes adapting the cavea to the characteristics of the site, the Romans built their constructions freely, ignoring the characteristics of the chosen site.Thanks to their technical-building skills, they developed the procedures required to make the architectural object completely independent from any environmental, natural or spatial constraint (perfecting it in the amphitheatre and exporting it throughout the Empire).

\section{Timeless geometry}

Let us now review which features of the exedra make it so unique. According to several scholars the first drawing of its design could be linked to the exedra above the 'upper sanctuary' of the Temple of Fortuna Primigenia (mid-second century B.C.). This huge hemicycle has rectilinear side wings and two rows of columns that create a double portico with curved naves. This concave space in turn encircles a stepped cavea with a span of roughly 47 metres. At the top of the exedra, a circular temple (of which only the foundations remain) crowned the complex, creating an interesting pattern of concave and convex lines. Another curvilinear building is present in the exedra-like Villa of Acqua Claudia in Anguillara Sabazia, built approximately one century after the Temple of Fortuna Primigenia. Its morphology clearly recalls the one in Palestrina since a similar approach was adopted;

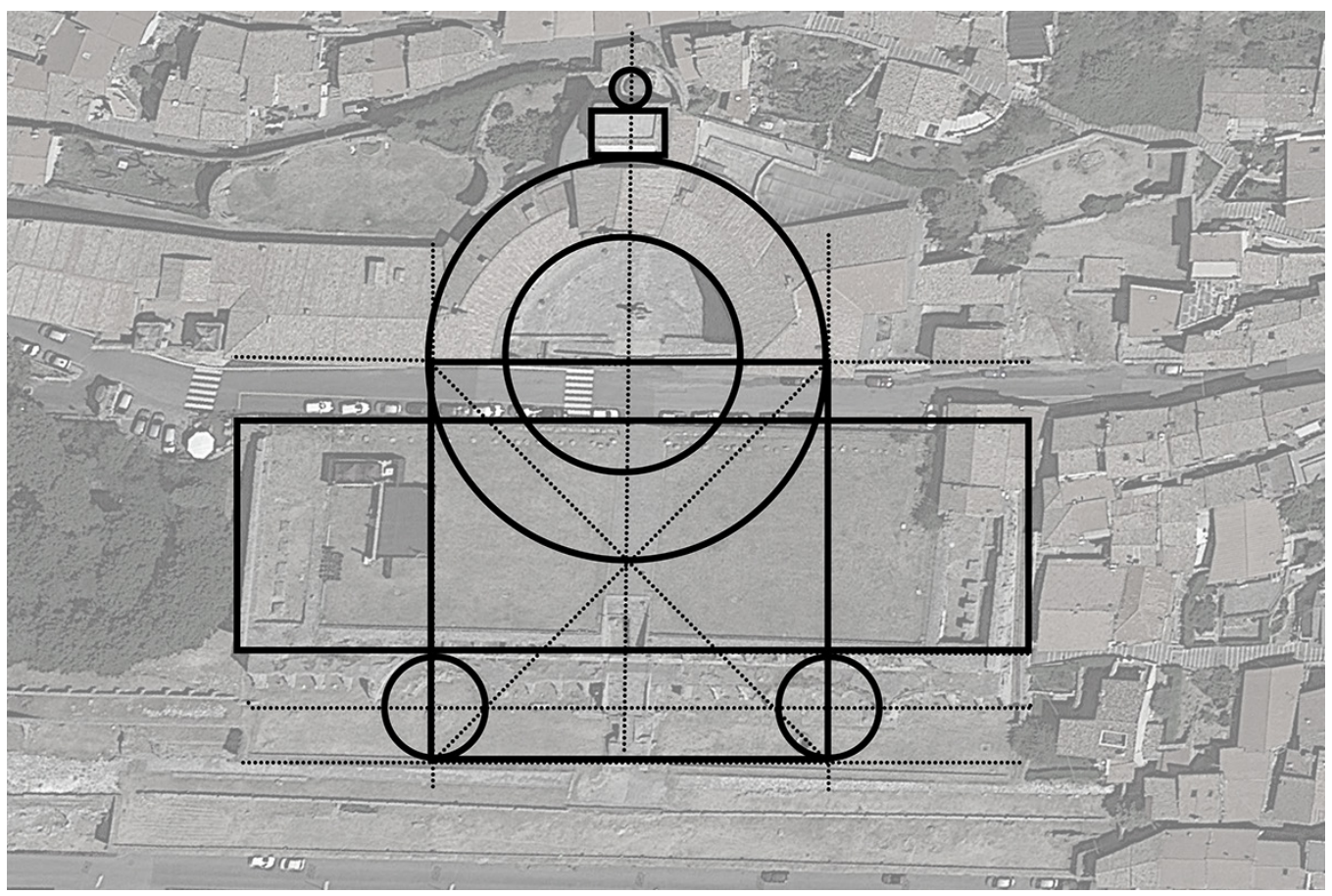


although it is based on a big exedra created by a circumference arc, it is still far from being a semicircle with linear and specular ends on either side. Nevertheless, the spatial novelty represented by the conformation with niches in the exedra triggers the feeling of enrichment and further dynamic movement.

Fig. 3. Roman ruins in the exedra Villa of Acqua Claudia in Anguillara Sabazia.

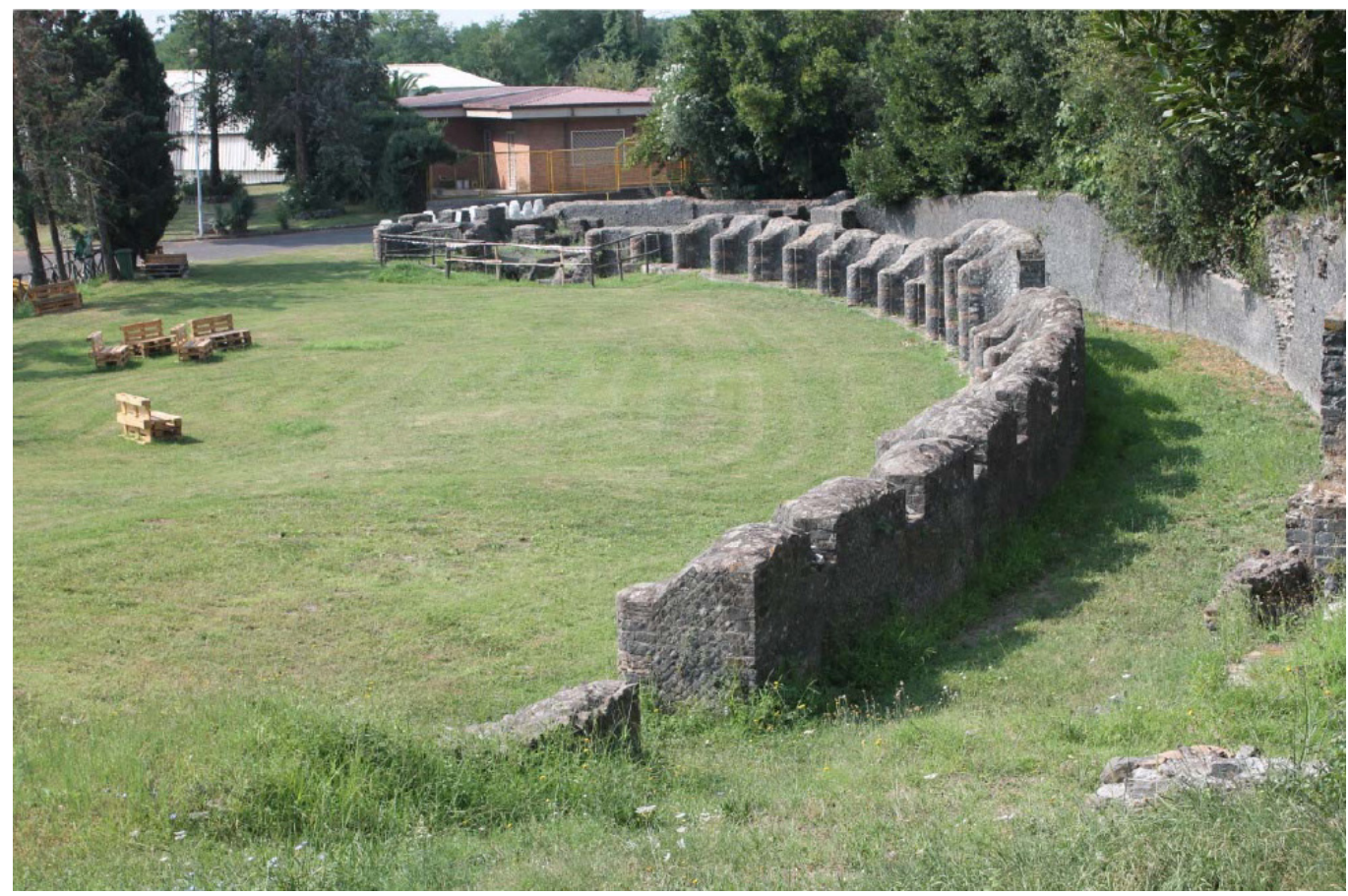

Curvilinear architecture is accentuated and "takes shape" noticeably in the construction of the Forum of Augustus in Rome. Here two pairs of symmetrical exedras, acting as tribunalia, are perpendicularly placed along the main axis of the Temple of Mars Ultor. Compared to the previous example, the exedra has aulic features, slowly becoming the symbol of grandiose Imperial architecture which "was to find in the curved line one of most original and effective means of expression, [...] where it was to achieve solemn effects that have remained unparalleled. Note [furthermore] how the degree of curvilinearity [...] already accentuated in the hemicycles of the Forum of Augustus, becomes a perfect semicircle in the exedra in Trajan's Market" [Vighi 194I, pp. I5I-153].

Vighi was an archaeologist who studied the Roman curved line. He proposes a connection with Trajan's construction. In fact, it is very likely that the maximum degree of sophistication in the application of the exedra is reached in Trajan's Markets. Amongst the many reasons for a curved form, the first is essentially structural. The exedra of the markets is constructively configured as an arch placed horizontally to contain the thrust of the earth of the hill behind it. In fact Trajan's Forum and markets were built after cutting through the saddle connecting the Quirinale and Campidoglio hills. Their morphology was dictated by a purely structural requirement, a curvilinear retaining wall -a monumental front shoring up the cut hillsidethat became a symbolic and strictly functional architectural manifesto. The Ulpia basilica also differs from older basilicas, the Julia and Aemilia, due to the presence of two apses with a diameter the length of the three internal naves. They formally dialogue with the exedras in the Forum, and also probably share the same function, that of a tribunalia.

These architectures clearly demonstrate how, compared to flat spatial involucres, the presence of an exedra (or an inflexed surface) provides three advantages: it bestows greater solemnity and majesty to the construction; it creates a better, skilful distribution of space; the 
third, but no less important advantage is that it produces a more remarkable scenic effect, leveraging perspective views and more grandiose chiaroscuro effects.

Seamlessly continuing on from Trajan's architecture, Villa Adriana (A.D. 76-I38) in Tivoli represents the summa of Roman compositional research in which the topic of the curved line was studied in-depth and further enhanced. In the villa three architectures appear to be the outcome of sophisticated compositional games merging extreme creativity and skilful construction: the mixtilinear environment of the Small Baths, characterised by an octagon with four convex sides; the Golden Square where the cruciform pavilion at the rear is characterised by an unusual, sinuous concave-convex shape; and the plastic solutions of the Maritime Theatre. Apart from these specific examples, the concept behind the entire villa represents a turning point in Roman architecture. Here, in fact, "the wall masses shape internal and external spaces" [Bozzoni et al. 2006, pp. 331, 332]; they are freed from the rule of architectural orders, but clearly reflect expressive objectives which, citing the modern architect Luigi Moretti, we can call "feelings of expansion".

Fig. 4. Geometric analysis ofTrajan's Markets.

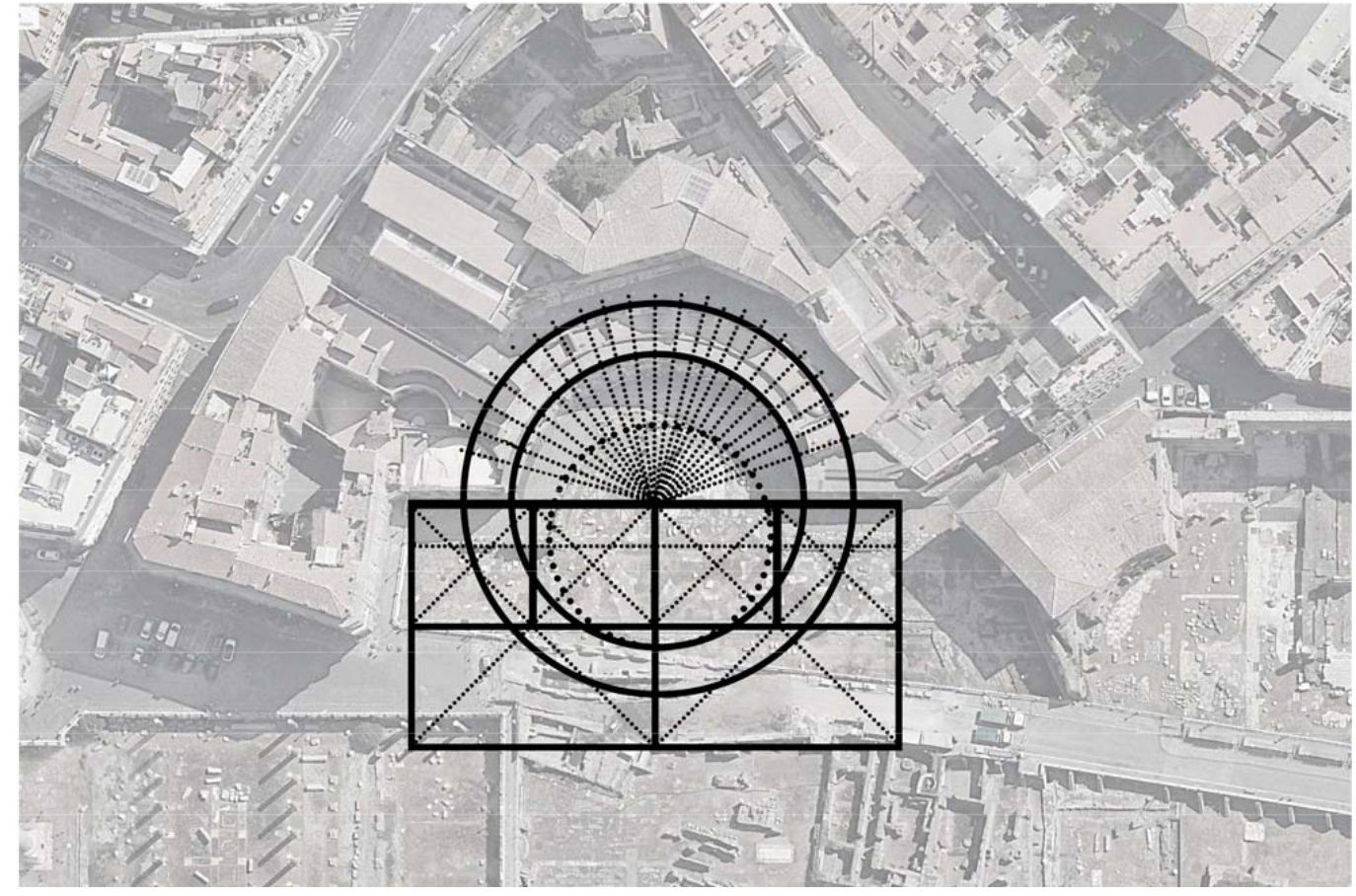

It is not therefore a gamble to ideally link the architecture of Villa Adriana to the Roman Baroque. Several historians and scholars agree, in fact some of them even state that "by then the curved line, brilliantly used in multiple combinations and more harmonious developments, was an integral part of the architectural language of Rome: it already influenced the features of admirable creations in Italy, and even more so in the provinces, the style of which, as a precursor of the seventeenth-century in Italy, has been called "ancient Baroque" Vighi 194I, p. 153].

In the seventeenth century there was a problem regarding the creation of an 'area' in front of St. Peter's Basilica. The monumental, representative space, acting as an antechamber to the basilica, had to reconcile several heterogeneous architectural, urban and functional elements. Gian Lorenzo Bernini (I598-1680) ultimately chose an ovato tondo which, compared to an ellipse, is easier to build; it was also conceptually congruous with the counterreformation policy launched by the church in response to the protestant ferment culturally rife in Europe. In fact, the ellipse was the 'heretical' representation of new sciences, while according to the Catholics, the oval was the correct evolution of the circle, a perfect geometric shape, and the basis of Euclidean geometry. 


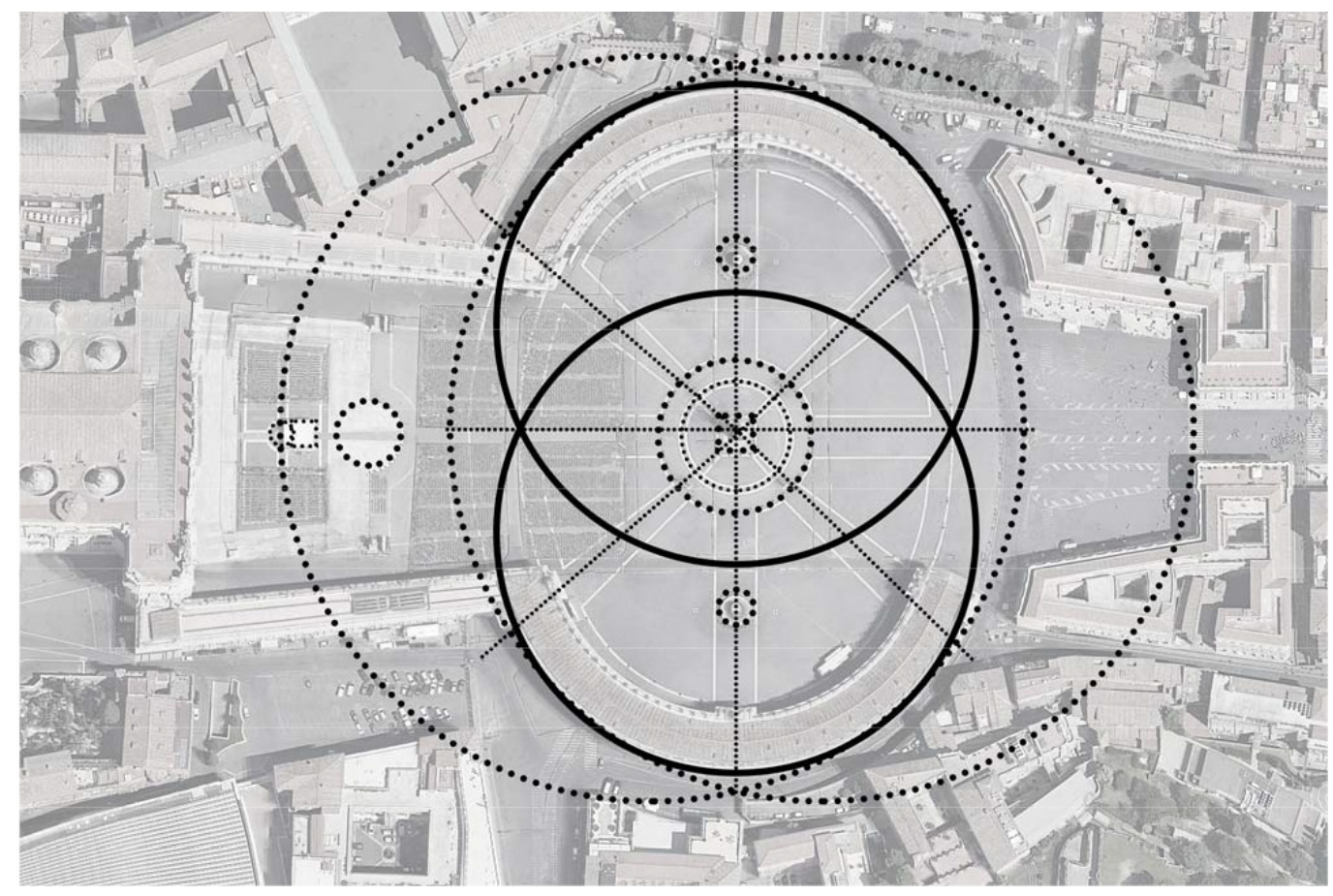

The design creates a dynamic space and overcomes the static nature and excessive regularity of the circle. On either side of the square two big exedras created by the circumference arcs are conformed by a forest of pilasters with a dual function: to filter pre-existing urban environments and symbolically embrace the faithful.

Perceptively speaking Bernini's choice is confirmed by Heinrich Wöfflin who wrote: "The baroque never provides satisfaction and an end, nor the calm of being, but the agitation of becoming, the tension of a changing state. And from this, in another manner, comes a new sense of movement. The 'tension of proportions'" belong to it. The circle is a calm, unchangeable form; the oval is restless and appears to tend towards continuous mutation. It lacks necessity. On principle the baroque creates these "free" proportions. The finite, the complete, is contrary to its nature" [Wöfflin 20I0, p. 72]. Wöfflin also comments on the curved line "supporting the movement of the eye that follows the line, redesigning it [...] and this would explain the pleasure induced by curved lines. The beauty of [curved] form would be identical to the convenience of the eye" [Wöfflin 20I I, pp. I4, I5].

Instead of focusing on Piazza del Popolo and its exedras designed by Valadier during the Napoleonic period, we will concentrate on the search for a national style after the Capture of Rome. It was Gaetano Koch ( I 849-19 |0) who designed Piazza della Repubblica (formerly Piazza Esedra). The idea behind the porticoed buildings was to place them over the ruins of the old Diocletian Baths and, in particular, the big Roman exedra. The fact Via Nazionale already existed forced the architect from the Tyrol to create two asymmetrical hemicycles, given the slight misalignment of the road compared to the centre of the exedra. Koch tried to correct this slight asymmetry by placing rectilinear profiles close to the entrance to Via Nazionale, making the difference almost imperceptible. This superimposition recalls what Sigmund Freud said about Rome when he emphasised the uniqueness of the capital and compared it to a psychic entity where things are stratified as they are in our conscience and, as if by magic, emerge conspicuously, merging with one another to create a unicum. More than 100 years earlier, in 1786, Johann Wolfgang Goethe (1749-1832), during his Travels in Italy, had intercepted the specific nature of Rome in that multilayered reality through which the new city rises from the old and both coexist in a single 'living body'. 


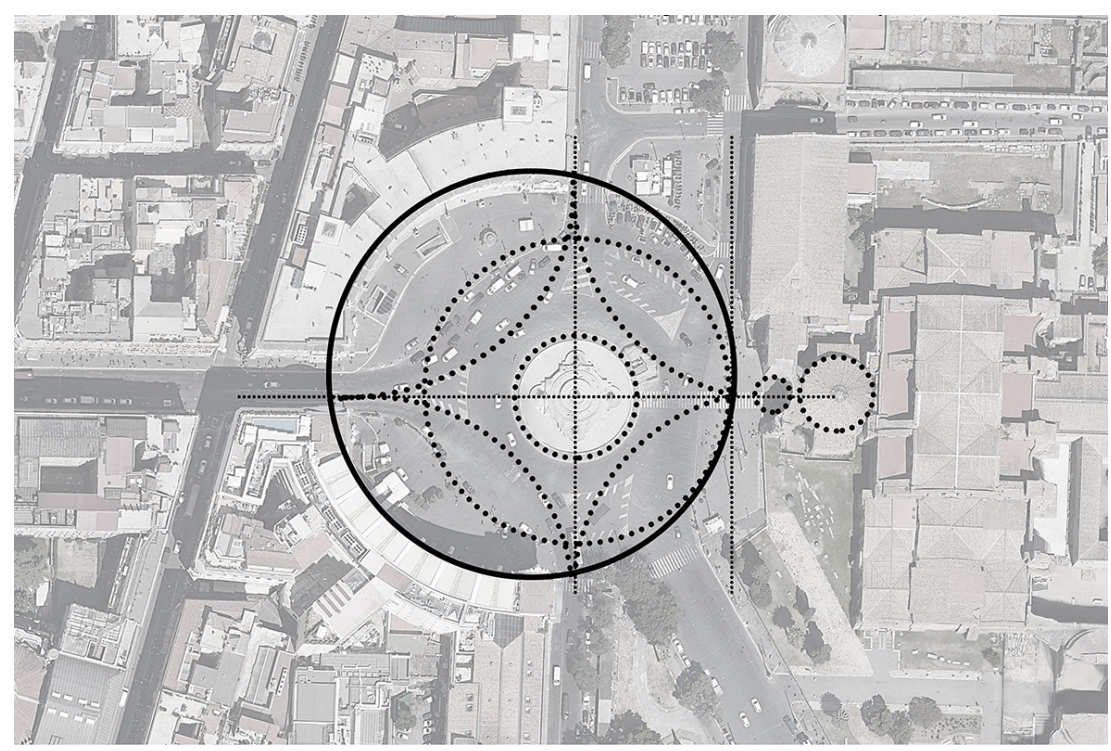

Fig. 7. Geometric analysis of Piazza del Popolo.
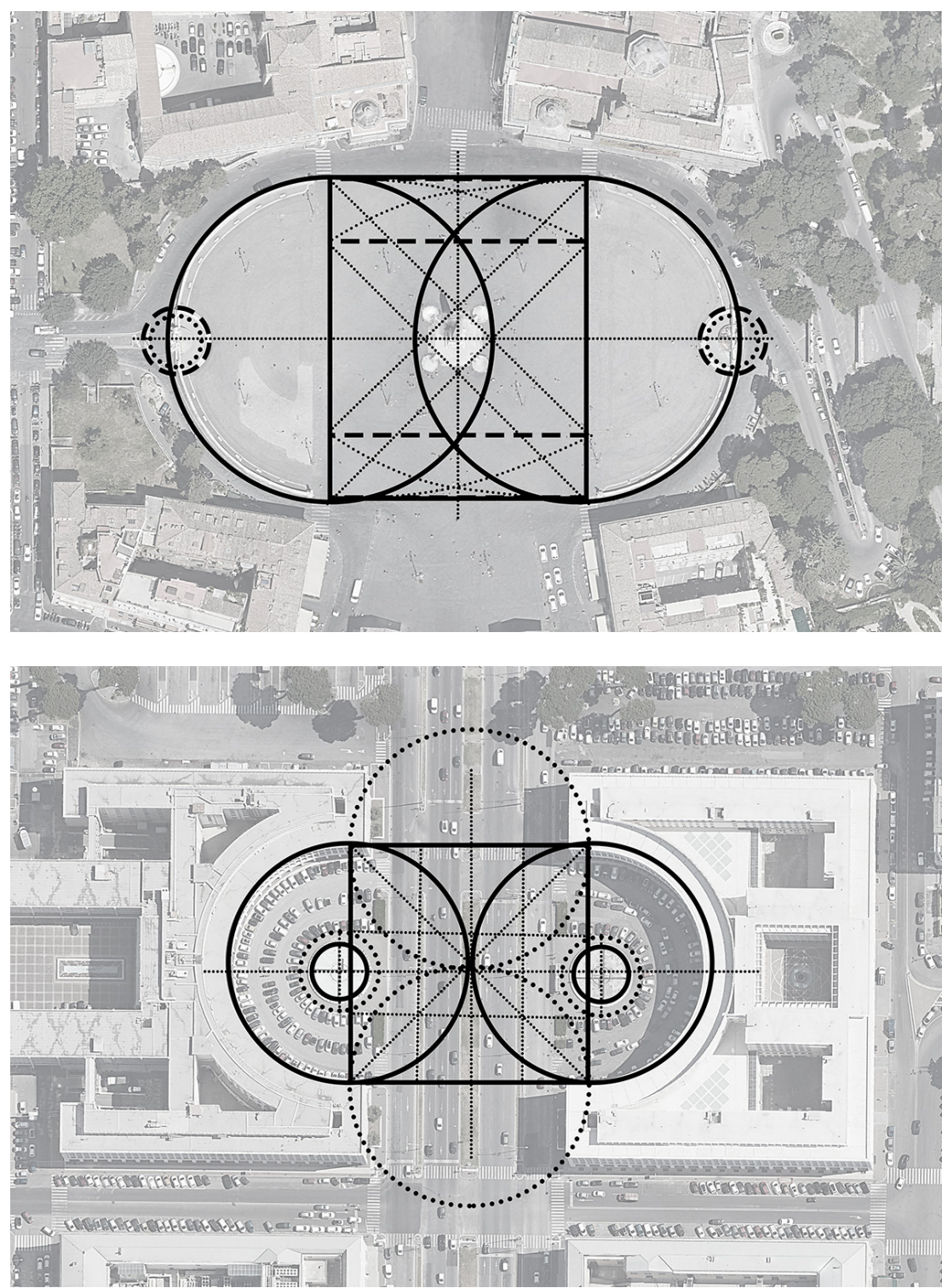
As part of the urban project for the Universal Exposition in 1942 -which we will not discuss here- two exedra buildings -inspired by Trajan's Markets- were designed by Giovanni Muzio, Mario Pediconi, and Giulio Paniconi as architectural wings on either side of the socalled "Imperial gate".

Their goal -to pick up the threads of the architectural spirit of ancient Rome- is more than evident in the competition for the Palazzo del Littorio to be built along the new road known as Via dell'Impero. It was 1934. Adalberto Libera (1903-1963) decided to design his project in such a way that it was ideally linked to the hemicycle in Trajan's Markets; he imbued the forms with symbolic importance -ranging from monumentality to mysticism- and tried to make the building dialogue directly with the apse of the nearby Basilica of Massenzio.

With just a few signs he succeeded in imbuing unity into the concept of classical abstraction and creating an image with absolute traits. Since the contract notice specified that there had to be a big space for rallies and assemblies, Libera solved the problem by using perspective projection. His project also included a big building delimited by two circumference arcs with different radii and transversal walls converging in a single point, midway between the centres of the two curvatures [Ciucci 200 I, p. 69]. In addition, the truncated ends reiterated the fragmentary nature of the building while the horizontal scansion of the front, achieved by using glass fascia, looks "as if the circle had dissolved into a curve at the scale of the landscape" [Garofalo 200 I, p. I5I].
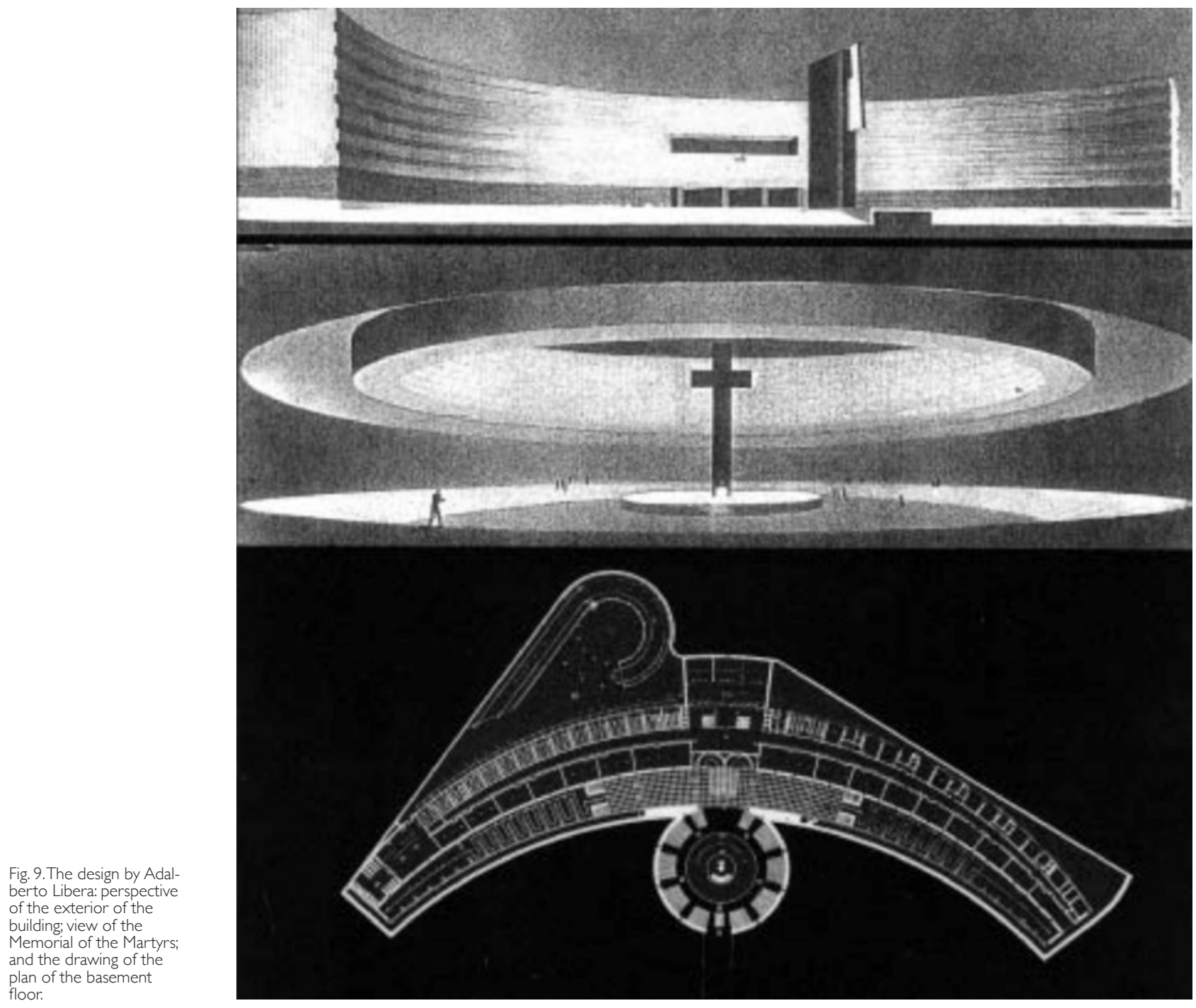


\section{Gestalt and archetypes of urban forms}

If we focus closely on the geometric geometries regulating and describing the aforementioned spaces, we could perhaps discover strong links with that part of flat geometry that for centuries has composed and built man's space. We're talking about initially drawing centres, then creating centrality, and subsequently establishing the radius in order to create the circumference or part of it, 'designing' the arc that will frame the respective scenic wing and establish and calculate the borders of the built space.

This geometric construction is based on the relationships of the circle, where everything is arranged with equidistant relationships between all the elements on the 'stage' compared to the centre of construction: We can use it to create continuous tensions and arrive at true balance [Arnheim 2002] by simply connecting the circumference radii with their respective centres. A perfect example would be Bernini's 'embrace' in St. Peter's Square; here the intersection between the two circumferences of the side exedras creates a third geometric figure, the oval, transforming a centripetal space into a centrifugal space; it also inspires a movement of perception in the onlooker, in this case assisted by the layout of the colonnade around the perimeter. We could define all this as a "dynamic visual experience" where the onlooker watches the interaction between the tensions of the two generating geometric figures which, according to Gestalt principles, generate a 'field' in which no object or part of it is perceived as being decontextualised or isolated from the rest, thereby ensuring that the entire space is characterised by a perceptive unicum.
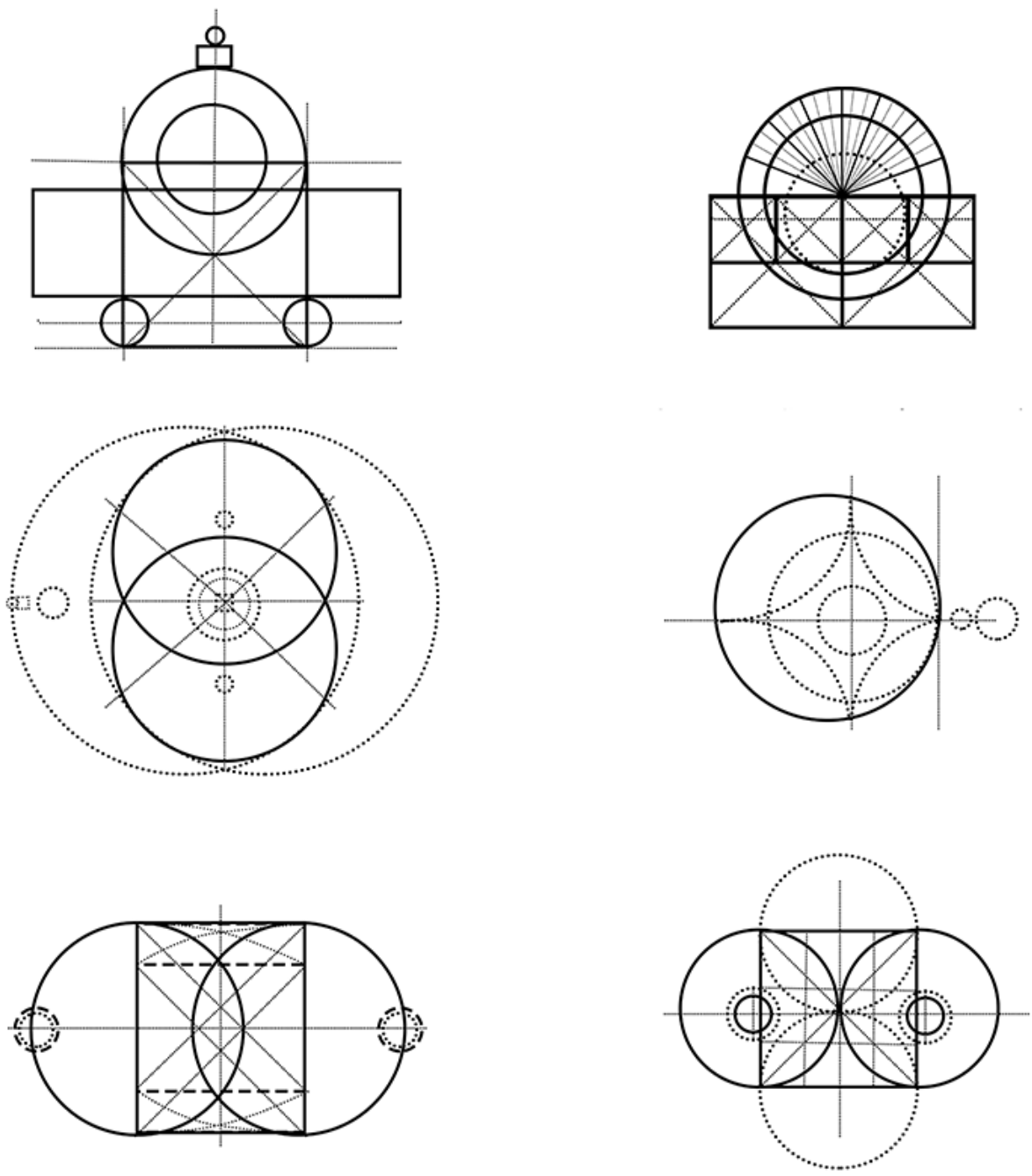
It follows that, ever since antiquity, the construction of curvilinear spaces has represented the 'archetypal force' of the Capital's culture: a distinctive trait that has been handed down through the centuries in different forms and has developed its own geometries; a 'collective sign' which, with the help of figures planimetrically recalling the 'mandala' [I], is capable of unequivocally representing the design of the city. The curve thus becomes an iconography of the forma urbis, the sign that best describes the Genius Loci and Rome's centuries-old culture.

\section{Conclusions and considerations}

The above considerations were inspired simply by observing the planimetric layout of the city and analysing its constituent elements. Our objective was to understand the genesis of a space, not only from a geometric, physical, and perceptive point of view, but also as regards its link with historical memory; we tried to trace the fil rouge which, down through the centuries, connects these architectural examples, and also to understand its 'meaning'. Tackling this topic from a perceptive-cognitive viewpoint enabled us to look beyond the evidence of a geometric frame and examine the fields of the unconscious in order to highlight the chthonic aspects of a culture, often hidden by an aesthetics of form, but revealed by the cultural bond characterising and uniting them through the ages.

These short considerations reveal a series of spatial relationships which, after some time, become the identity of a city, characterising its quality and features. With this in mind, it's important to try and broaden the field of study and include other sites in Rome which have only been slightly touched on here, for example Villa Madama, designed by Rafael, Piazza del Popolo, and the two exedras in the EUR district.

We should perhaps analyse all the various case studies more systematically to try and find the thin red line that often runs between many cities, but which nevertheless remains hidden between the folds of the urban fabric without succeeding in becoming visible and recognisable. The idea is that similar studies may outline a study method linked to the cognitive processes related to the development and perception of a form. In this case the exedra embodies an archetypical tradition developed by Roman philosophy; its natural evolution remains a mainstay that affects and influences other architectures in other places.

\section{Notes}

[I] According to C. G. Jung, the 'mandala', as orderly figures, both in antiquity and in the modern age, represent aesthetics and order, the ancestral need to rediscover our spiritual dimension, the mystic sense of life: man between heaven and earth striving to find a synthesis between the two worlds [Jung 1991].

\section{References}

Arnheim R. (2002). Arte e percezione visiva. Milano: Feltrinelli.

Benevolo L. (2004). San Pietro e la città di Roma. Roma-Bari: Laterza.

Bozzoni C. et al. (2006). L'architettura del mondo antico. Roma-Bari: Laterza.

Carpiceci A. C. (1983). La Fabbrica di San Pietro, venti secoli di storia e progetti. Firenze: Bonechi.

Ciucci G. (200 I). Lo stile di Libera. In AA.VV. Adalberto Libera. Opera completa, pp. 62-79. Milano: Mondadori Electa.

Finelli L., Foà Di Castro F. (a cura di) (200I). Giulio Pediconi: un testimone imparziale. Roma: Edizioni Kappa.

Garofalo F. (200 I). Progetto per il palazzo del Littorio a Roma. Concorso di I grado, 1933-34. In AA.V. Adalberto Libera. Opera completa, pp. I50- I5I, Milano: Mondadori Electa.

Jung C. G. (1972). Psicologia e Alchimia. Torino: Bollati Boringhieri [prima ed. Psychologie und Alchemie, 1935].

Jung C. G. (1977). Gli archetipi dell'inconscio collettivo. Torino: Bollati Boringhieri.

Jung C. G. (199I). L'uomo e i suoi simboli. Milano:Tea [prima ed. Man and His Symbols, 1964]. 
MacDonald W. L., Pinto J. A. (2006). Villa Adriana: la costruzione e il mito da Adriano a Louis Kahn. Milano: Mondadori Electa. Marconi P. (1964). Giuseppe Valadier. Roma: Officina Edizioni.

Muntoni A. (1987). Lo studio Paniconi e Pediconi 1930-1984. Roma: Edizioni Kappa.

Muratore G. (2007). Roma. Guida all'architettura. Roma: L'Erma di Bretschneider.

Quilici V. (198I). Adalberto Libera: l'architettura come ideale. Roma: Officina Edizioni.

Spagnesi G. (2003). Roma. La basilica di San Pietro, il borgo e la città. Milano: Jaca Book.

Tucci G. ( 1969). Teoria e pratica del mandala. In Palladio,V, 4, pp. I45- I60. Roma: Ubaldini.

Wöfflin H. (20l I). Psicologia dell'architettura. Milano: et al. [prima ed. Prolegomena zu einer Psychologie der Architektur. Basel: Schwabe AG Verlag, 1946].

Worringer W. (2008). Astrazione e empatia. Un contributo alla psicologia dello stile. Torino: Einaudi [prima ed. Abstraktion und Einfühlung. Ein Beitrag zur Stilpsychologie. München: Piper \& Co., 1908].

Wöfflin H. (20 I0). Rinascimento e barocco. Ricerche intorno all'essenza e all'origine dello stile barocco in Italia. Milano: Abscondita [prima ed. Renaissance und Barock. Eine Untersuchung überWesen und Entstehung des Barockstils in Italien. München: Bruckmann, 1888].

\section{Authors}

Luca Ribichini, Sapienza Università di Roma, luca.ribichini@uniroma l.it

Vito Rocco Panetta, Comune di Roma.

Antonio Schiavo, Sapienza Università di Roma, antonio.schiavo@uniromal.it

Lorenzo Tarquini, Sapienza Università di Roma, lorenzo.tarquini@uniromal .it

Ivan Valcerca, Sapienza Università di Roma, ivan.valcerca@uniromal.it

To cite this chapter. Ribichini Luca, Panetta Vito Rocco, Schiavo Antonio, Tarquini Lorenzo, Valcerca Ivan (2021). Exedra: il disegno dello spazio romano tra geometria e percezione/Exedra: designing space in Rome: geometry and perception. In Arena A., Arena M., Mediati D., Raffa P. (a cura di). Connettere. Un disegno per annodare e tessere. Linguaggi Distanze Tecnologie. Atti del $42^{\circ}$ Convegno Internazionale dei Docenti delle Discipline della Rappresentazione/Connecting. Drawing for weaving relationship. Languages Distances Technologies. Proceedings of the $42^{\text {th }}$ International Conference of Representation Disciplines Teachers. Milano: FrancoAngeli, pp. I063-1084. 